\title{
Eligibility Testing at 41BU75, Burleson County, Texas
}

Jennifer K. McWilliams

Texas Historical Commission

Karl W. Kibler

Cross Timbers Geoarcheological Services

John E. Dockall

Eloise Frances Gadus

Ross C. Fields

Follow this and additional works at: https://scholarworks.sfasu.edu/ita

Part of the American Material Culture Commons, Archaeological Anthropology Commons, Environmental Studies Commons, Other American Studies Commons, Other Arts and Humanities Commons, Other History of Art, Architecture, and Archaeology Commons, and the United States History Commons

Tell us how this article helped you.

This Article is brought to you for free and open access by the Center for Regional Heritage Research at SFA ScholarWorks. It has been accepted for inclusion in Index of Texas Archaeology: Open Access Gray Literature from the Lone Star State by an authorized editor of SFA ScholarWorks. For more information, please contact cdsscholarworks@sfasu.edu. 


\section{Eligibility Testing at 41BU75, Burleson County, Texas}

\section{Licensing Statement}

This is a work for hire produced for the Texas Department of Transportation (TxDOT), which owns all rights, title, and interest in and to all data and other information developed for this project under its contract with the report producer. The report may be cited and brief passages from this publication may be reproduced without permission provided that credit is given to TXDOT and the firm that produced it. Permission to reprint an entire chapter, section, figures or tables must be obtained in advance from the Supervisor of the Archeological Studies Branch, Environmental Affairs Division, Texas Department of Transportation, 125 East 11th Street, Austin, Texas, 78701 


\title{
ELIGIBILITY TESTING AT 41BU75, BURLESON COUNTY, TEXAS (CSJ NO. 0648-03-046)
}

\author{
by \\ Jennifer K. McWilliams \\ Karl W. Kibler \\ John E. Dockall \\ Eloise Frances Gadus \\ and \\ Ross C. Fields
}

Principal Investigator: Ross C. Fields

TECHNICAL REPORTS, NUMBER 96

Prewitt and Associates, Inc

Cultural Resources Services

Austin, Texas

PAI Nos. 207028 and 213023

ARCHEOLOGICAL STUDIES PROGRAM, REPORT NO. 159

Texas Department of Transportation

Environmental Affairs Division

Austin, Texas

January 2014

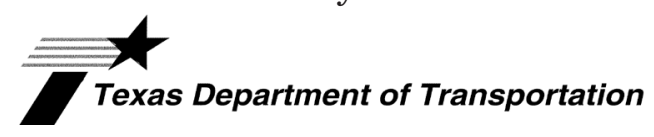

TEXAS ANTIQUITIES PERMIT NO. 4525 


\title{
ELIGIBILITY TESTING AT 41BU75, BURLESON COUNTY, TEXAS
}

\author{
COPYRIGHT @ 2014
}

Texas Department of Transportation (TxDOT)

This is a work for hire produced by the Texas Department of Transportation (TxDOT), which owns all rights, title, and interest in and to all data and other information developed for this project under Contract No. 57-7XXSA001, Work Authorization No. 57-714SA001, and

Contract No. 57-3XXSA003, Work Authorization No. 57-304SA003.

Brief passages from this publication may be reproduced without permission provided that credit is given to TxDOT and Prewitt and Associates, Inc. Permission to reprint an entire chapter, section, figures, or tables must be obtained in advance from the Supervisor of the Archeological Studies Program, Environmental Affairs Division, Texas Department of Transportation, 125 East 11th Street, Austin, Texas, 78701. Copies of this publication have been deposited with the Texas State Library in compliance with the

State Depository Requirement.

jointly published by the

Texas Department of Transportation

Environmental Affairs Division

Archeological Studies Program

Scott Pletka, Ph.D., Supervisor, Archeological Studies Program

Archeological Studies Program, Report No. 159

CSJ No. 0648-03-046

and

Prewitt and Associates, Inc.

Cultural Resources Services

Austin, Texas

PAI Nos. 207028 and 213023

Technical Reports, No. 96

Printed by Alphagraphics in Austin, Texas

ISBN 978-1-935545-26-2 


\section{TABLE OF CONTENTS}

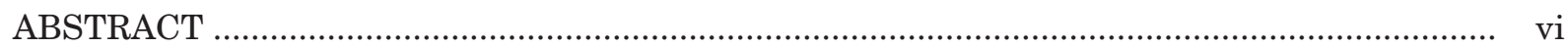

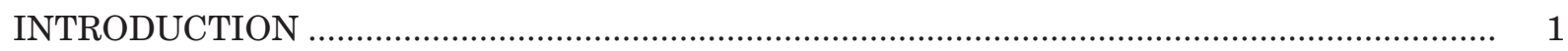

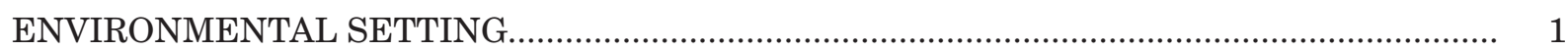

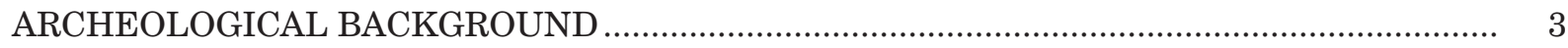

Paleoindian Period (10,000-6500 B.C.)............................................................................... 4

Archaic Period (6500 B.C.-A.D. 800) ….......................................................................... 4

Late Prehistoric Period (A.D. 800-1680) ..................................................................... 7

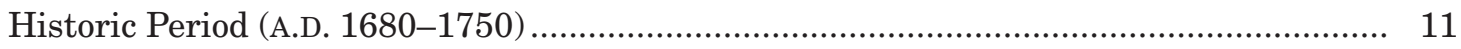

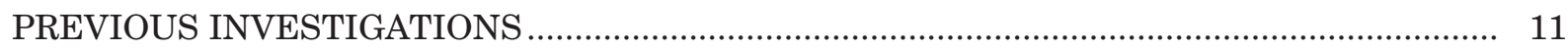

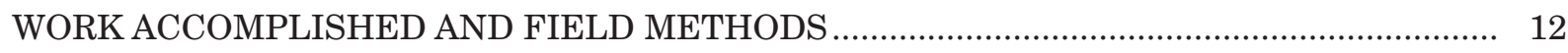

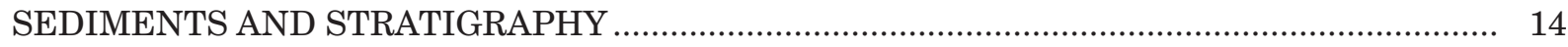

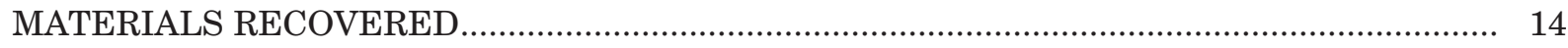

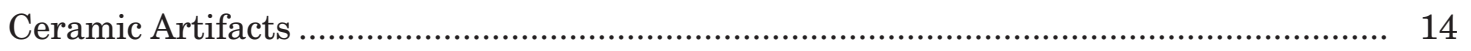

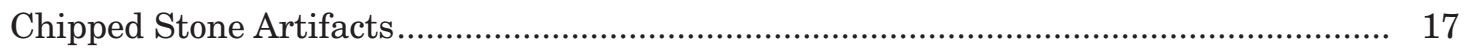

Ground and Battered Stones ............................................................................. 20

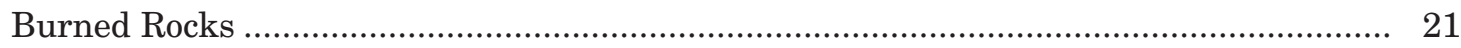

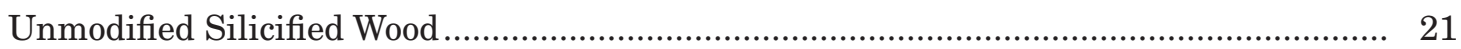

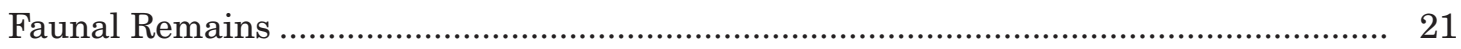

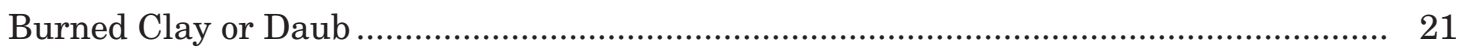

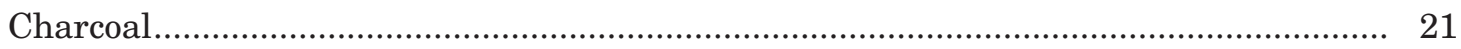

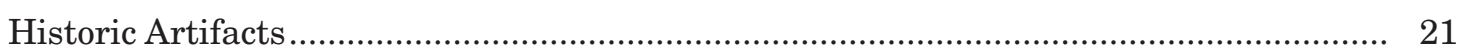

ARTIFACT DISTRIBUTIONS AND SITE COMPONENTS .................................................... 22

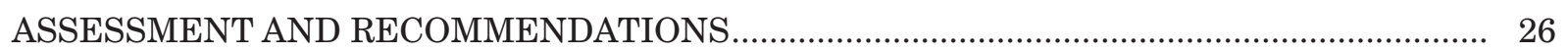

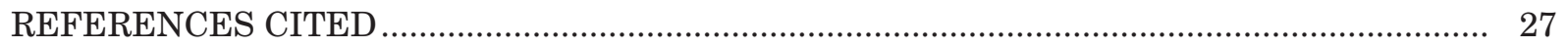




\section{LIST OF FIGURES}

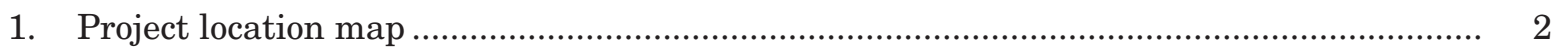

2. Plan of 41BU75 showing locations of Gradall trenches and test units ........................ 13

3. Photograph of the upper ca. $1 \mathrm{~m}$ of the west wall of Trench 3 ,

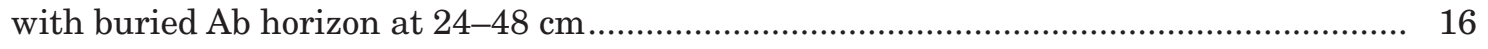

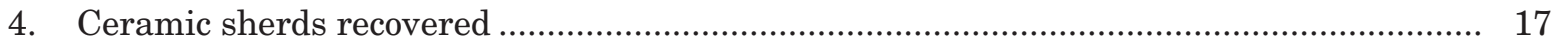

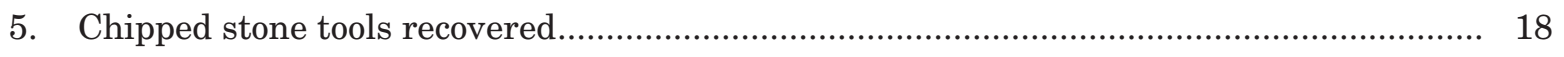

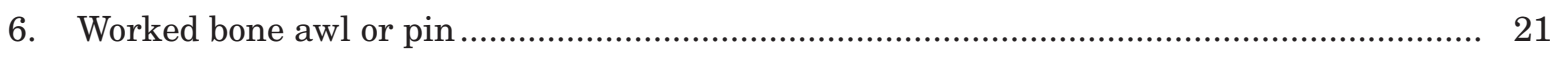

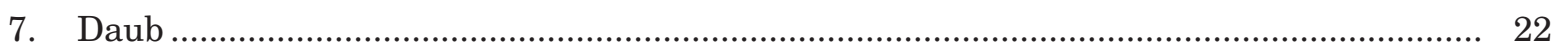

8. Graphs of artifact and burned clay/daub densities by depth in the test units................ 25 


\section{LIST OF TABLES}

1. Profile descriptions for selected trenches.

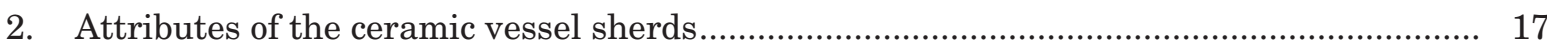

3. Provenience and metric data for the arrow points ....................................................... 19

4. Provenience and metric data for the unifaces and edge-modified flakes........................... 19

5. Provenience and metric data for the cores and tested cobble ......................................... 20

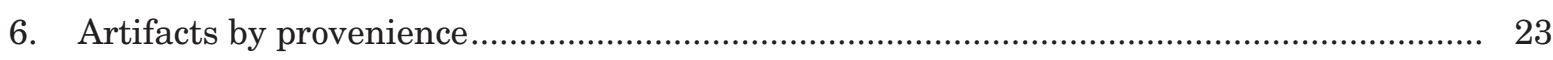




\begin{abstract}
Prewitt and Associates, Inc., conducted test excavations at site 41BU75 in Burleson County, Texas, to determine its eligibility for listing in the National Register of Historic Places and designation as a State Antiquities Landmark. The work was performed in 2007 under Texas Antiquities Permit No. 4525 for the Texas Department of Transportation, Environmental Affairs Division, in conjunction with a planned widening of FM 60, which will require up to $45 \mathrm{~m}$ of new right of way. The excavations consisted of six Gradall trenches and five 1x1-m hand-dug test units totaling $6.9 \mathrm{~m}^{3}$, all on stateowned land. Excavations yielded a small assemblage (ceramics, lithic tools, cores, and unmodified debitage) that is associated with Late Prehistoric and possibly earlier occupations. No cultural features were found. The artifacts were found throughout the sandy mantle, a mostly late Holocene colluvial depositional unit that varies greatly in thickness and is extensively bioturbated. It is recommended that 41BU75 be considered ineligible for listing in the National Register under Criterion D (36 CFR 60.4; 36 CFR 800.4, 5) or designation as a State Antiquities Landmark (13 TAC 26.2, 8) because interpretable components cannot be isolated and intact cultural features appear to be absent.
\end{abstract}

\title{
CURATION
}

All artifacts, records, and cultural materials generated by this project are curated at the Center for Archaeological Research at the University of Texas at San Antonio. 


\section{INTRODUCTION}

This report presents the results of test excavations conducted at 41BU75 in Burleson County, Texas, by Prewitt and Associates, Inc. The work was performed in 2007 for the Texas Department of Transportation (TxDOT), Environmental Affairs Division (ENV), under Contract No. 57-7XXSA001, Work Authorization No. 57-714SA001, to address the requirements of Section 106 of the National Historic Preservation Act and the Texas Antiquities Code. The project was prompted by the planned widening of FM 60 (CSJ No. 0648-03-046), which will require up to $45 \mathrm{~m}$ of new right of way. The area to be impacted by the road expansion (the horizontal Area of Potential Effects) is about 0.8 acres. The site likely will be impacted to its full depth, which is about 1-2 $\mathrm{m}$ below the surface (the vertical Area of Potential Effects). The new right of way is owned by the state, and the current investigations were conducted entirely on state-owned land.

The site was initially recorded in 2002 during a survey conducted by Prewitt and Associates along a ca. 13-mile stretch of FM 60 (Figure 1). Based on cultural materials recovered from shovel tests, the site was considered to have the potential to contain intact deposits. Therefore, it was recommended that the site be tested to assess its eligibility for the National Register. Test excavations were conducted in July 2007. An interim report recommending that the site be considered ineligible for National Register listing and State Antiquities Landmark designation was submitted in September 2007, and the Texas Historical Commission concurred with the recommendation. The project was reactivated in July 2013 when TxDOT issued Work Authorization No. 57-304SA003 (under Contract No. 57-3XXSA003) to produce this final report.

Site $41 B U 75$ is on a gently sloping Pleistocene terrace that stands $5 \mathrm{~m}$ above the floodplain of the Old River, which is an abandoned channel of the Brazos River. Sands ranging from 0.5 to $3.2+\mathrm{m}$ thick encase archeological materials on the terrace surface. It appears that this sandy mantle is mostly a late Holocene depositional unit, with weathering of the Pleistocene terrace deposits contributing sediments to it. Evidence from 41BU51 nearby (i.e., a paleosol near the bottom of the sandy mantle) substantiates the interpretation of the sands as a depositional unit (Broehm et al. 2010:15). When the site was recorded in 2002, it was in a hay field. As of 2007, it was a fallow pasture.

As described below, testing at 41BU75 through the excavation of six Gradall trenches and five 1x1-m hand-dug units resulted in the recovery of a modest artifact sample but no cultural features. Occupation could be limited to the Late Prehistoric period, but multiple components are possible. The site's ineligibility for listing in the National Register and designation as a State Antiquities Landmark stems from this uncertainty about the age of the cultural deposits, the inability to confidently isolate interpretable components, the lack of intact cultural features, and the extensive bioturbation.

The remainder of this report consists of eight sections. The first two provide environmental and archeological background information. The third describes the investigations at 41BU75 prior to the test excavations. The fourth describes the work accomplished during testing and the field methods. The fifth discusses the geomorphology of the site. The sixth section describes the cultural materials found in the excavations. The seventh section examines the horizontal and vertical distributions of the cultural materials and addresses the cultural components present. The final section offers assessments and recommendations.

\section{ENVIRONMENTAL SETTING}

Site $41 B U 75$ sits on a ridge about $5 \mathrm{~m}$ above the valley floor at the western wall of the Brazos River valley. A small unnamed drainage dissects the valley wall just west of the site and flows ca. $550 \mathrm{~m}$ north to Old River, a relict channel of the Brazos River. The current Brazos River channel is ca. $6.6 \mathrm{~km}$ to the north. Old River flows into the Brazos ca. $23 \mathrm{~km}$ southeast of the site, just upstream from where Yegua Creek joins the Brazos.

As discussed below, the landform containing 41BU75 is mapped as a Pleistocene fluvial terrace deposit that extends along the west margin of the Brazos River floodplain (Bureau of Economic Geology 1974). However, the sediments observed in the test excavations are more consistent with deposits of the Eocene Yegua Formation, which is mapped nearby, than 


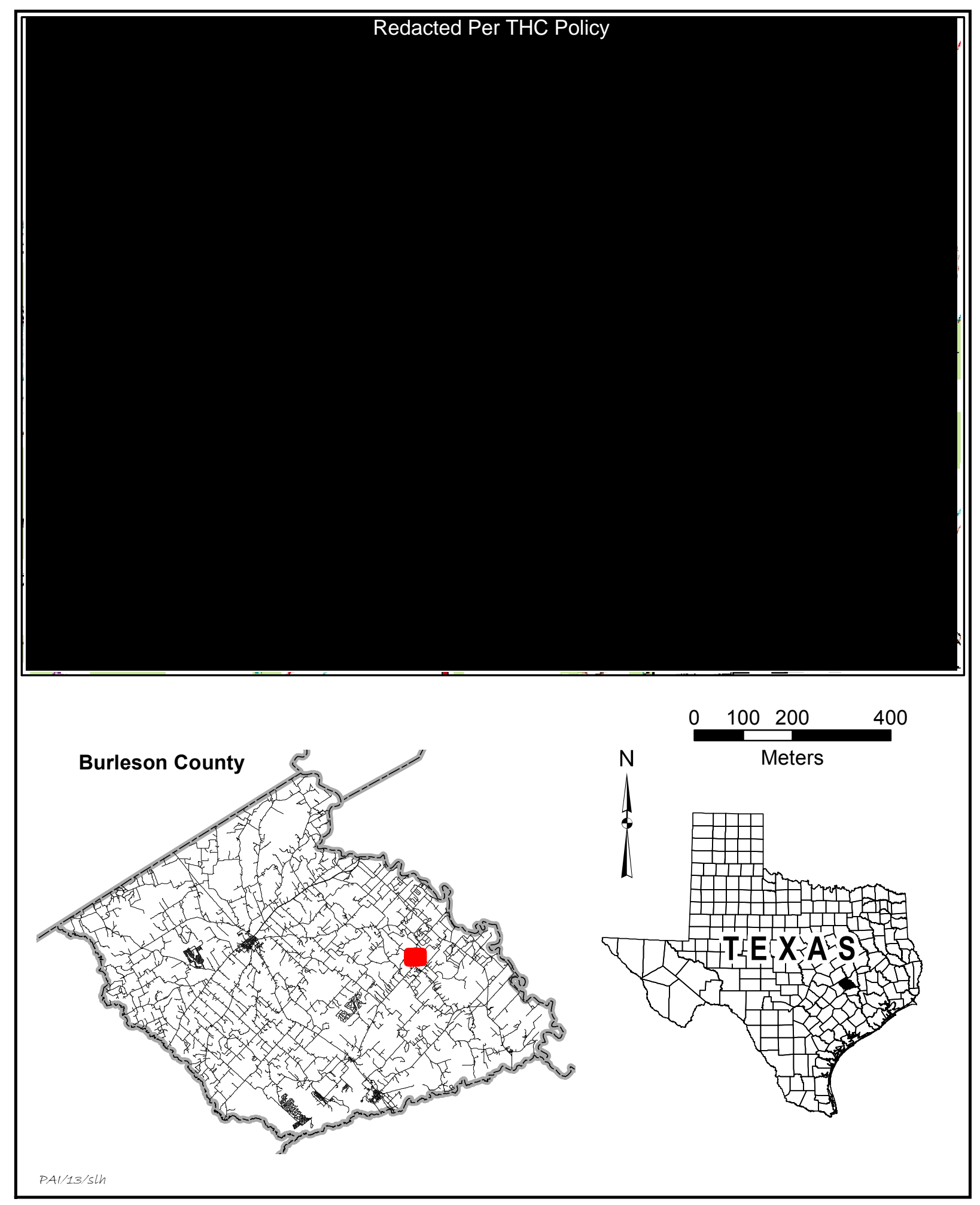

Figure 1. Project location map (USGS 7.5-minute Chances Store quadrangle). 
with Pleistocene terrace deposits. According to the U.S. Department of Agriculture's Web Soil Survey, Robco loamy fine sand developed in loamy colluvium derived from Eocene sandstones is mapped for the site area.

The project area is on a narrow swath of Blackland Prairie that is inset into the Oak Woodlands of east-central Texas (Diamond et al. 1987). The Oak Woodlands region is characterized by mainly deciduous forests (greater than 60 percent canopy cover) of the overcup oak and post oak-black hickory series, and mainly deciduous woodlands (20 to 60 percent canopy cover) of the bluejack oak-pine and post oakblackjack oak series. The Blackland Prairie is a tallgrass prairie characterized by the gamagrass-switchgrass, little bluestem-Indiangrass, and Silveanus dropseed series. Deciduous forests of overcup oak and post oak-black hickory are also found.

The project area is in the Texan biotic province, for which Blair (1950:101) notes at least 49 species of mammals. Blair (1950:101) and Davis (1974) have described this diverse mammalian assemblage as including whitetail deer, opossum, armadillo, raccoon, ringtail, weasel, mink, river otter, skunk, badger, red and gray fox, coyote, red and gray wolf, mountain lion, bobcat, ocelot, jaguar, beaver, peccary, bison, black bear, several species of bats, gopher, mole, squirrel, numerous species of mice and rats, rabbits, and jackrabbits. Bison and high-level predators have largely been extirpated. Other vertebrate fauna include at least 39 species of snakes and at least 41 species of lizards, skinks, box turtles, toads, frogs, and salamanders (Blair 1950:101-102). The region has 349 permanent or seasonal resident bird species and is within the Central Flyway, one of the four major bird migration routes in North America (Kutac 1994:47). Numerous freshwater fish and mussel species are also found in local streams and rivers (Chilton 1997; Howells et al. 1996).

The climate of the region is humid subtropical, with hot summers and mild winters. The average temperature is ca. $67^{\circ} \mathrm{F}$, with monthly averages ranging from $84^{\circ} \mathrm{F}$ in July to $47^{\circ} \mathrm{F}$ in January. The average annual precipitation is about $99.06 \mathrm{~cm}$ (39 inches), with a peak in the fall. Climate is mainly affected by the Gulf of Mexico, although strong fronts from the north can affect the region in the winter (Natural Fibers Information Center 1987:12, 73-74).

\section{ARCHEOLOGICAL BACKGROUND}

This summary outlines the Native American cultural history of the southern part of east-central Texas and encompasses the stretch of the Oak Woodlands extending from Freestone and Navarro Counties on the north to Bastrop and Fayette Counties on the south, with Burleson County in the middle. The archeology of parts of this area is well understood because archeological investigations involving excavations have been undertaken. Projects that have contributed important information include those conducted at Richland-Chambers Reservoir in Freestone and Navarro Counties (Bruseth and Martin 1987; McGregor and Bruseth 1987); Lake Limestone in Leon, Limestone, and Robertson Counties (Mallouf 1979); Jewett Mine in Freestone and Leon Counties (Day 1984; Fields 1987, 1990; Fields and Klement 1995; Fields et al. 1991; Gadus et al. 2002); Calvert Mine in Robertson County (Davis et al. 1987; Robinson and Turpin 1993); Sandow Mine in Lee and Milam Counties (Ricklis 2001; Rogers 1997, 1999; Rogers and Kotter 1995); Gibbons Creek Mine in Grimes County (Rogers 1993, 1994, 1995); Somerville Lake in Burleson, Lee, and Washington Counties (Peterson 1965; Thoms and Ahr 1996); Cummins Creek Mine in Fayette County (Kotter et al. 1991); Fayette Power Plant in Fayette County (Skelton 1977); 41BU16 and 41BU51 in Burleson County, 41MM340 and 41MM341 in Milam County, the Kennedy Bluffs and Bull Pen sites in Bastrop County, and the Black Hopper and Sandbur sites in Fayette County, all excavated because of Texas Department of Transportation projects (Bement et al. 1989; Broehm et al. 2010; Ensor and Mueller-Wille 1988; Fullem 1977; Gadus et al. 2006; Kalter et al. 2005; Mahoney et al. 2003; Roemer and Carlson 1987); and miscellaneous excavations such as those at the Winnie's Mound and Frisch Auf! sites (Bowman 1985; Hester and Collins 1969).

Given its location, it is not surprising that the archeology of this region often has been seen as reflecting influences from adjoining regions with better-defined cultural histories. For example, Caddo influences predominate in the northern part of the study area, coastal influences are especially strong on the southeastern edge, and central Texas influences are most pronounced on the southern and western margins. 


\section{Paleoindian Period (10,000-6500 B.C.)}

The earliest evidence of Native American occupation of the southern part of east-central Texas is attributable to the Paleoindian period. Although archeological remains from this period are scarce, a variety of early points have been found, largely in mixed or surface contexts. Presumably, the area was used by huntergatherer groups with low population densities and high residential mobility. One significant early find, estimated to date between 10,000 and 8000 B.C., was at the Duewell-Newberry site in Brazos County (Carlson et al. 1984). The find consisted of mammoth remains deeply buried in Brazos River alluvium. Although no artifacts were found in association, some of the bones contained cut marks indicating human modification.

Other early materials from the region include a few San Patrice points from RichlandChambers Reservoir (McGregor and Bruseth 1987:176-179); one Folsom point from Lake Limestone (Mallouf 1979:44); a Golondrina point, several untyped lanceolate points, and a radiocarbon assay of 9200-7300 B.C. from the Lambs Creek Knoll site at the Jewett Mine (Fields 1995:304), as well as a Clovis point, a Meserve-Dalton point, and two San Patrice points from two other sites (Day 1984:83; Fields et al. 1991:317).

Other artifacts include a San Patrice point and a Plainview-like point from the lowermost stratum at the Winnie's Mound site (Bowman 1985:44); a Meserve point from 41BU51 (Broehm et al. 2010:37; a Plainview point and a Golondrina point from the Chesser site and a Clovis point and possible Clovis blade in redeposited contexts at 41LE177 at the Sandow Mine (Ricklis 2001:150; Rogers and Kotter 1995:134); a few Dalton and San Patrice points from sites at the Gibbons Creek Mine (Rogers 1995:166); a Dalton point from Somerville Lake (Thoms and Ahr 1996:13); a few Plainview and Meserve points from sites in the Fayette Power Plant project area (Skelton 1977:124); and a handful of points from the Sandbur site, including Clovis and Folsom preforms, a Dalton point, a Firstview point, a Wilson point, two Golondrina points, and a possible St. Mary's Hall point (Kalter et al. 2005:112-118).

\section{Archaic Period \\ (6500 B.C.-A.D. 800)}

Many of the excavated sites in the region have components dating to the Archaic period, and it is clear that the area supported sizable populations by the last third of the period. Materials dating to the early and middle parts of the period are widespread but not abundant. For example, the relatively intensive work at Richland-Chambers Reservoir and Lake Limestone and Jewett Mine at the north end of the region suggests limited use of the western edge of the Oak Woodlands before the Late Archaic. However, for both areas it has been noted that data pertaining to the early to middle parts of the Archaic may be scarce in part because sites dating to this interval lie deeply buried or were removed by extensive erosion during the mid-Holocene (Fields 1995:302; McGregor and Bruseth 1987:229). Only a few radiocarbon assays predating 2000 B.C. were obtained from these project areas, and only one excavated site, Charles Cox at the Jewett Mine, contains a substantial component that might be Early or Middle Archaic in age (Fields 1995:303-305). A variety of untyped dart points with expanding and parallel stems appear to represent this component, but later materials are mixed in as well, and the deposits were not dated by radiocarbon. Points dated to this interval in central Texas-for example, Bell, Andice, Calf Creek, and Hoxie-occur at both RichlandChambers Reservoir and Jewett Mine, but only in very small numbers.

Similar conclusions can be reached for the other project areas listed above. The work at the Calvert Mine did not reveal evidence of significant Early to Middle Archaic occupations, and the evidence from most of the excavated sites at the Sandow Mine is limited as well-an early split-stem point, an Angostura-Hoxie point, and two Travis points from the Chesser site and a Martindale point from 41LE120 (Rogers 1997:52; Rogers and Kotter 1995:134). Site 41LE177 at the Sandow Mine contained an Early Archaic component represented by an Angostura point, an early split-stem point, a Uvalde point, two or three Hoxie points, and a hearth-debris cluster, as well as some perhaps redeposited Middle Archaic materials, including two Early Triangular points and a Travis point, but these components suffered from integrity and dating 
problems and were difficult to interpret other than noting that they probably reflected shortterm occupations for hunting-related activities (Ricklis 2001:143, 145, 150).

Early to Middle Archaic materials elsewhere in the region, all from sites that date predominantly later, include a Hoxie point from 41GM166 at the Gibbons Creek Mine (Rogers 1995:166-167); an Angostura-like point from Somerville Lake (Thoms and Ahr 1996:13); four Morrill, Nolan, and Carrollton points from 41BU51 (Broehm et al. 2010:57); a few Travis, Nolan, Hoxie, and Uvalde points from the Cummins Creek Mine (Kotter et al. 1991:111, 124, 136); single Gower and Angostura points from the Fayette Power Plant (Skelton 1977:124, 125); and a Travis point from the Black Hopper site (Fullem 1977:11).

Three excavated sites with substantial Early to Middle Archaic components are Winnie's Mound, Kennedy Bluffs, and Sandbur, although the primary components at all three appear to be later. At Winnie's Mound, a Bell point, a Hoxie point, five Gower-Uvalde-like points, two Gowerlike points, and five Hoxie-Gower-Uvalde-like points were found in the lower strata, along with at least one hearth (Bowman 1985:43-47, 70). At Kennedy Bluffs, only a few Early to Middle Archaic points (one Travis, one Tortugas-Taylor, two Angostura, one Gower-like, and one Nolan) were found in the area excavated, but many items dating to this interval were documented among the materials collectors recovered from another part of the site (Bement et al. 1989:3536, 71-154). At Sandbur, one Angostura point, nine Bell/Andice points, one Hoxie point, one Merrill point, eight Wells points, and a single Early Triangular point were found, perhaps associated with burned rock concentrations (Kalter et al. 2005:118-124). Given the limited information available for this part of the period, it is difficult to say much about adaptations and lifeways. It does appear, however, that the region was used in a limited fashion, presumably reflecting low population densities among mobile hunter-gatherers.

The late part of the Archaic period-after about 2000 B.C.- presents a very different picture. All parts of the area that have been studied archeologically contain sites dating to this period, and the Late Archaic represents the earliest time for which much is known about Native American lifeways. The greater visibility of Late
Archaic materials may be partly a function of earlier remains having been removed by erosion or masked by deposition in some locales, but it is speculated that it also relates to increased population densities. One of the more-complete pictures of the archeology of the Late Archaic for this region comes from the north edge of the area. Along Richland and Chambers Creeks, Late Archaic groups appear to have been huntergatherers whose subsistence pursuits focused on wild plant foods such as hickory nuts and prairie turnip and faunal taxa such as deer, turtles, small mammals, birds, and fish (McGregor and Bruseth 1987:236-240). Although presumably not sedentary, these groups clearly used the area for residential purposes, and populations appear to have increased. A conspicuous component of the record is the so-called Wylie pit, examples of which were excavated at the Bird Point Island and Adams Ranch sites. These were large features that appear to have been used for communal processing of vegetal resources (and later as cemeteries), perhaps in the context of band aggregation in tension zones as territories decreased in size (McGregor and Bruseth 1987:237).

The Navasota River valley and the area eastward to and across the Trinity River divide also were occupied with increased intensity during the Late Archaic period (Fields 1995:307-309), although there is no evidence for the kind of population aggregations indicated at Richland-Chambers Reservoir. Faunal and macrobotanical remains were not preserved in the Late Archaic components at Lake Limestone and Jewett Mine, except for the ubiquitous hickory nuts, and thus data on subsistence are limited. Nonetheless, it is surmised that these hunter-gatherers subsisted on a variety of wild plant foods and game, especially deer. Of the 20 excavated components assigned to this period, 15 are interpreted as residential bases and 5 as procurement or processing locations. Five of the residential-base components are situated along the Navasota River and appear to represent general-purpose campsites, and the others are in the uplands to the east and consist of 2 general-purpose residential bases and 8 residential bases at which activities focused heavily on plant processing and secondarily on hunting. This distinction suggests that Late Archaic settlement systems were based on the occurrence of plant foods. The analysis units interpreted 
as procurement-processing locations appear to have focused primarily on plant processing and then on hunting-related activities. Four of these are along streams in the uplands, and the fifth is along a Navasota River tributary to the west. The data from these 20 components are consistent with the idea that Late Archaic groups were chiefly foragers because procurement-processing locations suggesting logistical use are not frequent. Settlement systems appear to have been highly scheduled, probably by season, with residential sites in riverine settings differing from those in the uplands. Comparisons with earlier components at Lake Limestone and the Jewett Mine are difficult, but the much greater frequency of Late Archaic components and the overall greater intensity of use suggest increased population densities, decreased territories, or both. The occurrence of a Late Archaic cemetery at the Cottonwood Springs site along Lambs Creek on the east side of the Navasota River valley also points to this shift (Fields and Klement 1995).

Not only do constellations of projectile point styles (e.g., Dawson, Gary, Godley, Kent, Neches River oletha, and Yarbrough) from the RichlandChambers, Lake Limestone, and Jewett Mine areas indicate ties to the north and east rather than to the south and west, but each of these areas also has yielded information suggesting that ceramics may have been introduced into the material culture of local groups during the latest part of the Late Archaic, as they were across most of Texas to the east (where this interval usually is called the Early Ceramic period and sometimes the Woodland period).

At Richland-Chambers Reservoir, distinctive shell-tempered sherds were recovered from contexts dated between A.D. 200 and 700 at the Adams Ranch site (McGregor and Bruseth 1987:180-181), apparently representing the earliest ceramic industry in this part of the Trinity River basin. At Lake Limestone and the Jewett Mine, a few shell-tempered sherds, a few sherds with a fine kaolin paste but no obvious temper, and larger numbers of sandy paste ceramics and grog- or bone-tempered ceramics were found in contexts that appeared to predate arrow points (i.e., the latter part of the Late Archaic). Although some of these could be genuinely early, especially the sandy paste wares that are so reminiscent of the early ceramics that predominate in east Texas south of the Sabine River, it is possible that the other sherds intruded from later deposits (Fields 1995:308). In either case, sherds were sufficiently infrequent to suggest that, although ceramic containers may have been a notable addition to the material culture, they were not abundant.

The Late Archaic archeology of the other project areas in southern east-central Texas has not been deciphered to the same extent as that at Richland-Chambers Reservoir and Jewett Mine, but it is clear that similar, though not identical, cultural developments occurred within huntergatherer groups across the region. The single excavated site at the Calvert Mine, 41RT267, apparently contains a Late Archaic component, but small sample sizes and the lack of features hamper interpretation (Robinson and Turpin 1993). Two of the excavated sites at the Sandow Mine- the Chesser site and the Walleye Creek site-contained abundant Late Archaic remains. At these sites, many burned rock features were found in association with dart point types such as Bulverde, Pedernales, Lange, Marshall, Marcos, Ensor, Darl, and Fairland (Rogers 1999:96; Rogers and Kotter 1995:134). Although these types show distinct ties to central Texas in general, Rogers (1999:96-97) argues that the last three represent more-local types especially common to the eastern margin of the Edwards Plateau. Site 41LE177 at the Sandow Mine yielded only one Bulverde point and apparently did not see substantial use during the Late Archaic period (Ricklis 2001:150). A single sandy paste sherd was recovered from the Chesser site, but it is unclear if it relates to terminal Archaic or Late Prehistoric use of the site. In either case, ceramics were a less-prominent part of the material culture here than they were farther to the east and north. The limited faunal and macrobotanical remains recovered suggest reliance on Carya nuts and deer (Rogers 1999:28, 31-32; Rogers and Kotter 1995:42-45, C-1-10).

To the east, three sites along the Brazos River-Winnie's Mound, 41BU16, and 41BU51have significant Late Archaic components (Bowman 1985; Broehm et al. 2010; Roemer and Carlson 1987). Perhaps most important, all three contained cemeteries probably at least partly Late Archaic in age. Cemeteries here and elsewhere across the region perhaps represent increased population densities and definition of territories. The projectile point styles recovered-Bulverde, Darl, Dawson, Edgewood, 
Ensor, Fairland, Frio, Gary, Godley, Kent, Lange, Marcos, Pedernales, and Yarbrough —are a mix of types characteristic of central and eastern Texas. Winnie's Mound and 41BU51 yielded very small samples of sandy paste sherds, and 41BU16 contributed a larger ceramic collection that is hard to relate typologically to ceramics in surrounding regions.

Not far north on the Little River in Milam County, both 41MM340 and 41MM341 have Late Archaic components, although only the one at 41MM340 was investigated intensively (Gadus et al. 2006; Mahoney et al. 2003). This site, which was occupied from about 1400 to 400 B.C., contained numerous hearth features represented by both burned rock clusters and charcoal and burned clay concentrations. Subsistence data indicate that the hunter-gatherers who occupied the Little River valley at this time consumed the meat of a variety of fauna, including mussels, deer, bison, turtles, beaver, rabbits, raccoon, opossum, skunk, turkey, ducks, and fish. Botanical remains were not as abundant, although nutshell fragments indicate that hickory and pecan nuts were part of the diet. Most of the dart points belong to types that firmly tie the region to central Texas to the west at this time, including Darl, Ensor, Godley, Marcos, Marshall, and especially Pedernales. Some more-eastern types, such as Gary, Kent, and Yarbrough, are represented, however.

At the Gibbons Creek Mine on the east edge of the study area, most of the excavated sites have Late Archaic components, and Rogers (1995:167) suggests that this reflects "a less mobile population relying more heavily on the area's plant resources, particularly hickory nuts." Rock hearths are common at these sites, but other kinds of features are not. Not surprisingly, the most common dart point types-Gary, Kent, and Palmillas-show strong connections to the eastern part of the state rather than to central Texas (Rogers 1995:167). As at Jewett Mine and Richland-Chambers Reservoir to the north, ceramics may have been added to the material culture during the latest Archaic. These early ceramics were sandy paste wares comparable to early ceramics elsewhere in southeastern Texas (Rogers 1995:167).

At Somerville Lake on Yegua Creek, the single site excavated, Erwin's Bridge, contained many Late Archaic artifacts, although it was difficult to isolate this component from the Late
Prehistoric component (Peterson 1965). Most of the kinds of projectile points recoveredBulverde, Castroville, Darl-like, Elam, Fairland, Palmillas, and Pedernales—resemble those from the Sandow Mine not far to the northwest, with both collections indicating ties to central Texas to the west. Erwin's Bridge yielded a small collection of ceramics, primarily sandy paste, but it is impossible to tell if these relate to the Late Archaic or Late Prehistoric occupations.

Moving farther south into the Colorado River basin, the Kennedy Bluffs and Bull Pen sites in Bastrop County, most of the tested sites at the Fayette Power Plant and the Cummins Creek Mine, and the Sandbur site in Fayette County have Late Archaic components. Both the Kennedy Bluffs site and the Bull Pen site, and perhaps the Sandbur site, contained evidence of extensive use of burned rock features associated with point styles typical of central Texas to the west, especially Pedernales. Other point types include Bulverde, Marcos, Montell, and Marshall-like at Kennedy Bluffs; Ensor, Fairland, and Darl at Bull Pen; and Lange, Marshall, Castroville, Montell, Marcos, Ensor, Fairland, Darl, and Godley at Sandbur (Bement et al. 1989:21-30, 37-44; Ensor and MuellerWille 1988:181-183; Kalter et al. 2005:124-133). These sites have been interpreted as seasonal base camps used repeatedly by hunter-gatherers for a variety of maintenance, extractive, and processing tasks (Ensor and Mueller-Wille 1988:183-200). At the Fayette Power Plant, a number of sites yielded similar styles of pointsPedernales, Marshall, Ensor, Darl, and Fairland. The last three types were especially common and indicated "a marked increase in site utilization and exploitation of the local resources" during terminal Archaic times (Skelton 1977:125-126). Several of the tested sites at the Cummins Creek Mine contained Darl, Ensor, Pedernales, and Mahomet points and were interpreted as having been used as short-term campsites during the Late Archaic period (Kotter et al. 1991:118-119, 159-160, 177).

\section{Late Prehistoric Period (A.D. 800-1680)}

Sites dating to the Late Prehistoric, after ca. A.D. 800, also are common across most of the region. As for the preceding period, good data on how Native Americans used the north part of the 
area comes from Richland-Chambers Reservoir and Lake Limestone and nearby Jewett Mine. Sites dating to this interval are frequent at Richland-Chambers Reservoir, especially for the early half of the period, and it appears that there was a significant decline in population densities after about A.D. 1300 (McGregor and Bruseth 1987:245). The data suggest that most of the excavated sites with Late Prehistoric components were used for residential purposes (McGregor and Bruseth 1987:241, 244, 246), although there are some sites, for example the streamside concentrations of mussel shells and artifacts at $41 \mathrm{FT} 193$ and $41 \mathrm{NV} 139$, that probably had more-limited use. The house patterns at the Bird Point Island site point to use by sedentary hunter-gatherers during the first half of the period, and other components that are contemporaneous, slightly earlier, or later (for example, at Bird Point Island, Adams Ranch, Irvine, and Little Cedar Creek) have middens and many features suggesting substantial use but no houses. These components may represent occupations that were seasonal in length. Macrobotanical remains point to use primarily of wild plant foods-hardwood nuts, a variety of seeds, tubers, and rhizomes (McGregor and Bruseth 1987:243). The only tropical cultigen is maize, and it occurs in very small quantities only in contexts dating to the last half of the period, so groups who lived in this area were predominantly hunters and gatherers. Alba, Scallorn, and Steiner arrow points were used during the early part of the period, and Perdiz and Cliffton points are more characteristic of the late part. Gary dart points may have been used through the early Late Prehistoric (McGregor and Bruseth 1987:183). Ceramics are moderately common and clearly relate to Caddo wares, with most of the identified types (for example, Maydelle Incised, Poyner Engraved, and Weches Fingernail Impressed) indicating contact with groups in the Neches River drainage, east of the Trinity.

Work at Lake Limestone along the Navasota River and Jewett Mine in the uplands to the east identified 12 components dating predominantly to the Late Prehistoric period, although not all are well dated (Fields 1995:313-317; Gadus et al. 2002). Six are interpreted as residential bases, and the other 6 are procurement-processing locations. These sites suggest that the Late Prehistoric period saw a change in settlement strategies from the Late Archaic and that there were changes within the Late Prehistoric period as well. During the early part of the period, residential activities were increasingly restricted to lowland sites, while the uplands were used mostly for hunting-related procurement and processing tasks. This pattern indicates that logistical strategies became more important, but there is no evidence that groups also became more sedentary within the upper Navasota River basin itself. Only one site, McGuire's Garden, contained the kinds of features and other remains that suggest permanent (or nearly so) occupation, with this unusually sedentary use dating to a short interval around A.D. 1300 (Gadus et al. 2002:155). During the late part of the period, the area apparently saw a return to forager-oriented hunter-gatherer strategies entailing more equable use of upland and lowland settings. Faunal remains indicate that deer, turtles, and rabbits were hunted commonly, and other small mammals, bison, fish, birds, lizards, and snakes were represented as well. Hickory nutshells are by far the most common plant remains. The only evidence for horticulture is from the McGuire's Garden site. Scallorn and Steiner are the most common early arrow point styles, and use of dart points appears to have persisted through the early part of the period (Fields 1995:314). Perdiz is the dominant later arrow point style. Ceramics occur widely but infrequently, being common at only a handful of sites that date mostly to the middle and late parts of the period. Nonetheless, they all relate strongly to Caddo wares from east of the Trinity River, with the more-distinctive sherds showing typological affinities to early types such as Holly Fine Engraved and Weches Fingernail Impressed and later types such as Maydelle Incised, Killough Pinched, Poyner Engraved, and Patton Engraved. Because Caddo ceramics are present in these components but evidence for permanent occupations (i.e., structures) is scarce, Fields et al. (1991) suggested that Caddo Indians used most of these sites as base camps to support forays by hunting parties or other procurement and processing task groups, or perhaps groups in transit between the eastern and central parts of the state used them. It is equally plausible, however, that local hunter-gatherer groups created them and that the ceramics resulted from trade or borrowing of ideas about ceramic manufacture and decoration. 
At the Calvert Mine in the uplands between the Brazos and Navasota Rivers, the primary component at the single excavated site, 41RT267, appears to date to the early Late Prehistoric period (Robinson and Turpin 1993:23-69). It contained Scallorn, Alba, and Granbury points, as well as a single sherd and several burned rock features, and was interpreted as having been used mostly as a hunting camp with occasional use as a domestic campsite (Robinson and Turpin 1993:71-72).

Moving southwestward across the Brazos River, 41MM341 on the Little River has a significant early Late Prehistoric component dating mostly from A.D. 800 or 900 to 1300 (Gadus et al. 2006). This site contains numerous surface hearths, pit hearths, processing pits, shell lenses, burned rock concentrations, possible postholes, and lithic reduction debris piles. Arrow points are typed primarily as Scallorn, Alba, and Perdiz, and the site also contained many finely chipped bifacial knives. Three bone-tempered sherds and one sandy paste sherd were recovered, but it is not clear if they belong with the early Late Prehistoric component or a much sparser later component. Site 41MM341 is interpreted as a campsite occupied perhaps mostly during the summer months by hunter-gatherers who took mussels and fish from the river and hunted a variety of game, especially deer, on the Little River floodplain and the surrounding uplands. They may have used botanical resources less, although they did consume hardwood nuts and wild onion and false garlic bulbs. One important activity performed at the site was manufacture of stone tools, mostly arrow points, knives, and expedient flake tools, using chert collected from gravel bars in the river. Many of these tools were used in the wide variety of procurement, processing, and manufacturing activities that typified daily life at 41MM341, but some appear to have been made because they would be needed later in the year after people left the site. One anticipated need was for trade with the Caddo Indians of east Texas. The evidence indicates that the people who lived at 41MM341 and other sites in the Little River valley interacted regularly with the Caddo, perhaps in trade relationships that helped cement cooperative alliances aimed at regulating competition among groups.

Farther south at the Sandow Mine, all three excavated sites have Late Prehistoric components, but they do not appear to represent intensive use. Materials diagnostic of this period include small numbers of Scallorn, Perdiz, Alba, and Cuney points; ceramics are scarce to absent (Ricklis 2001:150; Rogers 1999:96; Rogers and Kotter 1995:136). At Somerville Lake not far to the southeast, arrow points typed as Alba, Cliffton, Granbury, Perdiz, Scallorn, and Young were recovered from the Erwin's Bridge site, along with a handful of undecorated sherds (Peterson 1965:22-27, 36-43); small numbers of Alba, Scallorn, Perdiz, and Bonham points and sandy paste sherds were found at other sites Thoms and Ahr (1996) recorded in this area.

Eastward along the Brazos, early Late Prehistoric components represented by small numbers of Scallorn points, a few sandy paste sherds, and burials were documented at Winnie's Mound (Bowman 1985:43, 50, 61-63). Site 41BU51 nearby had a similar assemblage, with Scallorn and Edwards points (as well as a very late triangular point) and sandy paste ceramics; most of the burials there appear to predate the Late Prehistoric period, although it is possible some do not (Broehm et al. 2010:56-57). Site 41BU51 also contained abundant burned clay, some of which appears to be wattle-impressed daub possibly representing structural remains (Broehm et al. 2010:49-50). While this daub certainly is morphologically similar to daub from burned houses at Caddo sites to the east, there is no reason to think that Caddo Indians built houses at 41BU51. This conclusion is based on two lines of evidence: (1) much or all of the burned clay at 41BU51 probably predates the Late Prehistoric Caddo period; and (2) the site contained no Caddo pottery (Broehm et al. 2010:46, 58). Alba, Perdiz, and Scallorn points were found at 41BU16 in this same area, along with both sandy paste and bone- or grog-tempered ceramics (Roemer and Carlson 1987:8093); some of the burials at 41BU16 could relate to the Late Prehistoric component as well.

At the Gibbons Creek Mine at the southeast edge of the area, Late Prehistoric remains are well represented, with substantial occupations at 41GM281 and 41GM282 and more-limited occupations at several other sites (Rogers 1993:77, 102, 174, 214, 1994:154, 1995:138-143, 164-165). The predominant early and late arrow point styles are Scallorn and Perdiz, respectively. The ceramics from most of the excavated sites (Rogers 1993:102, 160-173, 210-212, 1994, 1995:108-123, 168-171) are the 
sandy paste ware that occurs throughout southeast Texas, first in Late Archaic (or Woodland or Early Ceramic) contexts and then in some Late Prehistoric contexts (e.g., on the upper coast). Two sites (41GM281 and 41GM282) also have sizable samples of pottery tempered with grog or bone. Some of these probably are related to the Late Prehistoric San Jacinto ware that occurs on the upper coast to the east and southeast, and small numbers of sherds bear designs similar to those seen on Caddo pottery to the northeast. Subsistence data from the Gibbons Creek Mine are especially sparse, but hardwood nutshells occur in most sites and liliaceous bulb fragments were recovered from a single site (Rogers 1993:74, 124, 214, 1994:120, $149,1995: 56,153)$. Consistent with the lack of cultigens at Gibbons Creek is the low stable carbon isotope value on human remains from a Late Prehistoric burial at 41GM205 (Rogers 1993:D-1 through D-3). The combined evidence indicates that, for the most part, the Gibbons Creek sites represent short-term residential occupations by hunter-gatherers.

In the Colorado River basin at the south end of the study area, Late Prehistoric components are well represented at comparatively few sites. At the Cummins Creek Mine, only one minor Late Prehistoric occupation is represented by a single untyped arrow point from one of the four sites tested (Kotter et al. 1991:154). The Black Hopper, Kennedy Bluffs, and Bull Pen sites all contained sparse Late Prehistoric materials indicating limited occupations; arrow point types consisted of Scallorn, Perdiz, and Granbury, with none of the sites yielding ceramics (Bement et al. 1989:47; Ensor and Mueller-Wille 1988:116-118; Fullem 1977:12-13). The most substantial excavated Late Prehistoric components in this area were at the Cedar Bridge site at the Fayette Power Plant (Skelton 1977:127-128) and the Sandbur site (Kalter et al. 2005:217-221), where Toyah occupations represented by Perdiz arrow points, bone-tempered ceramics, and bison bones were sampled. Sandbur also contained an earlier Late Prehistoric component represented mostly by Scallorn points, and maybe by sandy paste pottery. Another important Late Prehistoric component in the area was at the Frisch Auf! site, where Scallorn points and bone-tempered ceramics were found in association with a cemetery (Hester and Collins 1969).
As noted above, an important issue relating to the Late Prehistoric archeology of this part of the Oak Woodlands concerns the relationships between groups who lived in this area, and on the Blackland Prairie to the west, and Caddo groups who lived to the east. In most cases, the presence of Caddo artifacts west of the Caddo heartland has been seen as reflecting the movement of Caddo hunters or traders, which was well documented in early historic narratives, and perhaps the establishment of seasonal or year-round occupations at some locations. Adopting a different perspective on the movement of peoples and goods, Harry Shafer (2006) has proposed that the groups who used some of these western sites with Caddo materials during the period from A.D. 1000 to 1300 were Caddo people who were local to the area and who served as the sustaining population for the ceremonial center at the George C. Davis site in Cherokee County far to the east. This "Prairie Caddo" model is based in part on the limited evidence of habitation sites of the right age near the Davis site and the prevalence of an artifact assemblage that Shafer sees as the material correlate for a Prairie Caddo social identity. This assemblage includes Caddo vessel ceramics similar to those found at the Davis site, Alba-Bonham arrow points, Gahagan knives, and bone needles and metapodial beamers representing the manufacture of fine deer-hide clothes. Items within this assemblage (except beamers) occur at the Davis site both in burial and nonburial contexts (Shafer 1973; Story 1972), and Shafer (2006) demonstrates that these items are common at Blackland Prairie sites along and just east of the Balcones Escarpment, although they do not always (or maybe even often) occur together.

While acknowledging that parts of Shafer's Prairie Caddo proposal are compelling, Gadus et al. (2006:177-181) offer an alternative interpretation, arising from their analysis of the J. B. White site (41MM341) on the Little River at the boundary between the Oak Woodlands and the Blackland Prairie. They conclude that the Little River valley and those of its tributaries were used in a consistent fashion by local huntergatherer groups who were well-adapted to the Blackland Prairie and the ecotonal areas at its east and west margins from at least A.D. 600 to 1300, with consistency farther back into Late Archaic times suggested by 41MM340 nearby. 
Among the resources that these people knew how to exploit were the local chert gravels. By A.D. 1100 or a century or two earlier, they were using these gravels to make not only tools for their own use but also as goods to be used during interactions with the Caddo. This production involved particular tools following specific technological styles, but the evidence for interaction involving lithics not manufactured to such specifications (and not focused so strongly on a single east Texas site) goes much farther back in time, suggesting that this pattern of connections between the eastern margin of central Texas and the eastern part of the state was a persistent one rooted in long-held traditions. This has been documented, for example, at the Jewett Mine in Freestone and Leon Counties, where a number of caches of bifacial and unifacial tool blanks of central Texas materials have been found, and where large quantities of debitage reflecting the staged reduction of central Texas cherts have been identified in sites of various ages, including some dating to Late Archaic and even earlier times (Fields 1995:325). As noted above, ethnohistoric accounts indicate that substantial interaction between the two regions continued up to historic times, primarily in the form of Caddo groups traveling westward to hunt and trade. The reasons for this interaction may have changed over time, but the persistence of the pattern did not.

Contrary to what the Prairie Caddo model proposes, Gadus et al. (2006:177-181) think that the people who lived along the Little River in early to middle Late Prehistoric times were not ethnically Caddo peoples who provided support for the ceremonial center at the Davis site. Rather, they suggest they were a local group well adapted to their particular environs who interacted regularly with the east Texas Caddo, probably in simple face-to-face or maybe downthe-line trade relationships with limited dependencies and great group autonomy. This model also can be applied to groups who occupied the Brazos River valley during this time, including those who created 41BU51.

\section{Historic Period (A.D. 1680-1750)}

Native American archeological materials dating to the protohistoric and early historic periods are scarce in southern east-central Texas. In fact, materials of this age are so rare as to be almost invisible archeologically in the project areas discussed above. But ethnohistoric accounts make it clear that historic Native Americans, both resident groups and immigrants, occupied the area (Bolton 1970; Campbell 1988; Foster 1998; Newcomb 1993). Further, three historic routes from south Texas to east Texas-Camino de los Tejas, Camino Arriba, and La Bahia Road-passed through present-day Bastrop, Brazos, Burleson, Fayette, Grimes, Lee, Leon, Madison, Milam, Robertson, and Washington Counties by the seventeenth and eighteenth centuries (McGraw et al. 1991:9; Thoms 1993:12, 22). In the late 1740s and early 1750s, the Spanish located three missions-San Francisco Xavier de Horcasitas, San Ildefonso, and Nuestra Señora de la Candelaria-and a presidio (San Francisco Xavier de Gigedo) near one of these routes, not far from where Brushy Creek joins the San Gabriel River in Milam County (Gilmore 1996a, 1996b). The impetus for this came when members of the Yojuane, Deadose, Mayeye, and Ervipiame asked that a mission be established in their territory. Other Native American groups reportedly associated with the missions were the Asinia, Top, Nabedache, Akokisa, Bidai, and Coco. For a variety of reasons, the Spanish had abandoned their efforts along lower Brushy Creek by the mid-1750s (Newcomb 1993:16-17).

\section{PREVIOUS INVESTIGATIONS}

Site 41BU75 was recorded in 2002 during a survey by Prewitt and Associates in advance of the planned widening of FM 60 (McLoughlin 2002). The site was described as a prehistoric campsite that appeared to extend ca. $70 \mathrm{~m}$ northsouth and at least $40 \mathrm{~m}$ east-west, probably beyond the new right of way to the east but not west of FM $60 .{ }^{1}$ Six shovel tests were excavated, and all contained cultural materials. Materials recovered consisted of 81 pieces of lithic debris and 1 possible bison astragalus. Recovery from the shovel tests indicated that artifacts were most abundant at depths of $20-60 \mathrm{~cm}$ but occurred as deep as $100 \mathrm{~cm}$, i.e., the expected full thickness of the sands atop the Pleistocene terrace. Because parts of the site extended below the plowzone and were thought to have the

\footnotetext{
1 Testing by TxDOT in 2013 revealed that the site does extend west of FM 60 (Barnett and Abbott 2013).
} 
potential to contain intact deposits, test excavations were recommended.

\section{WORK ACCOMPLISHED AND FIELD METHODS}

Test excavations consisted of six Gradall trenches ranging from 8 to $9 \mathrm{~m}$ long and 1.0 to $3.2 \mathrm{~m}$ wide and five $1 \mathrm{x} 1-\mathrm{m}$ test units adjacent to four of the trenches (Figure 2). Trenches 1-5 were stepped for safety, and Trench 3 collapsed after excavation, requiring additional stepping. Trenches were oriented generally north-south throughout the new right of way. The trenches reached depths of 0.8 to $3.2 \mathrm{~m}$, and with the exception of Trench 4 (described below), each trench was excavated to the subsurface clay (the Pleistocene terrace. Trench walls were cleaned and examined for cultural materials, which determined the placement of the $1 \mathrm{x} 1-\mathrm{m}$ test units. Trench floors were inspected for intrusive cultural features.

All of the manual excavations started at the modern ground surface, and four out of five reached the bottom of the Holocene sandy mantle. The test units were excavated in $10-\mathrm{cm}$ levels, and all sediments removed (totaling ca. $6.9 \mathrm{~m}^{3}$ ) were screened through 1/4-inch-mesh hardware cloth.

Testing was initiated with up to $5 \mathrm{~m}^{3}$ of hand-dug excavations, with up to $3 \mathrm{~m}^{3}$ additional reserved as a contingency if needed to resolve outstanding issues affecting eligibility. The contingency was implemented to investigate the high-density artifact distribution in the lower levels of three of the five units. Written permission from TxDOT-ENV was acquired prior to the additional excavation. Based on the results of initial shovel testing, it was projected that the test units would not exceed $1.0 \mathrm{~m}$ in depth; however, variation in the thickness of the sandy mantle was dramatic, reaching at least $3.2 \mathrm{~m}$ in one part of the site.

The work authorization also specified that trenches should be excavated to the subsurface clay. As mentioned above, this was accomplished in Trenches 1-3, 5, and 6; Trench 4 did not reach the clay prior to the excavation of Test Unit 2 . After Test Unit 2 was completed, the backhoe was brought in, and the trench was excavated to $3.2 \mathrm{~m}$ below the surface until it encountered sand with patchy sandy clay. At that point, trenching was terminated due to safety concerns.
Trench 1, on the higher southern part of the terrace, reached the red sandy clay at a depth of $0.95 \mathrm{~m}$. A few artifacts were observed in the trench walls, and Test Unit 5 was placed on the east wall of the trench. Relatively sparse artifacts were recovered from this unit. Trench 2 was placed ca. $10 \mathrm{~m}$ north of Trench 1 and reached clay at $1.50 \mathrm{~m}$. Few artifacts were observed in the walls after cleaning; therefore, no test unit was excavated.

Trench 3 was placed ca. $10 \mathrm{~m}$ north of Trench 2. A dark brown paleosol was observed at $0.24-0.48 \mathrm{~m}$ below the surface, and basal clay was not reached during initial excavation of the trench. Numerous flakes and several burned rocks were observed in the trench walls. Test Unit 1 was placed at the south end of the trench. Test Unit 1 produced significant numbers of artifacts, including diagnostic lithics and ceramics, so a second unit (Test Unit 3) was placed on the west side of the trench. It also produced numerous artifacts. Clay was reached at 1.47 and $1.50 \mathrm{~m}$ in Test Units 1 and 3 . After the units were completed, the trench floor was scraped with a backhoe to expose the clay and inspect for intrusive features. None were observed.

Trench 4 was placed $12 \mathrm{~m}$ north of Trench 3 on the lower part of the ridge slope. The trench was initially excavated to ca. $1.20 \mathrm{~m}$ without reaching the basal clay. The dark brown paleosol was clearly visible at $0.40-0.60 \mathrm{~m}$. Numerous flakes were observed in the walls, and a historic ceramic sherd was found at ca. $0.75 \mathrm{~m}$. Test Unit 2 was established on the east side of the trench; it produced numerous artifacts. The unit was excavated to $2.00 \mathrm{~m}$ and did not expose basal clay. At that point, the trench floor was scraped; no intrusive features were observed. The backhoe then deepened the trench to $3.2 \mathrm{~m}$ below the surface, still without reaching the bottom of the sandy mantle. Trenching was terminated due to the possibility of wall collapse in the unstable sands.

Trench 5 was placed $12 \mathrm{~m}$ east of Trench 3. Few artifacts were observed in the trench walls. The dark brown paleosol was visible at $0.18-0.46 \mathrm{~m}$. The trench was excavated to $1.0 \mathrm{~m}$ but did not expose basal clay. Test Unit 4 was set up at the far north end of the trench. The unit, which produced a moderate number of artifacts, reached basal clay at $1.1 \mathrm{~m}$. The trench floor was then scraped, but no cultural features were observed. 


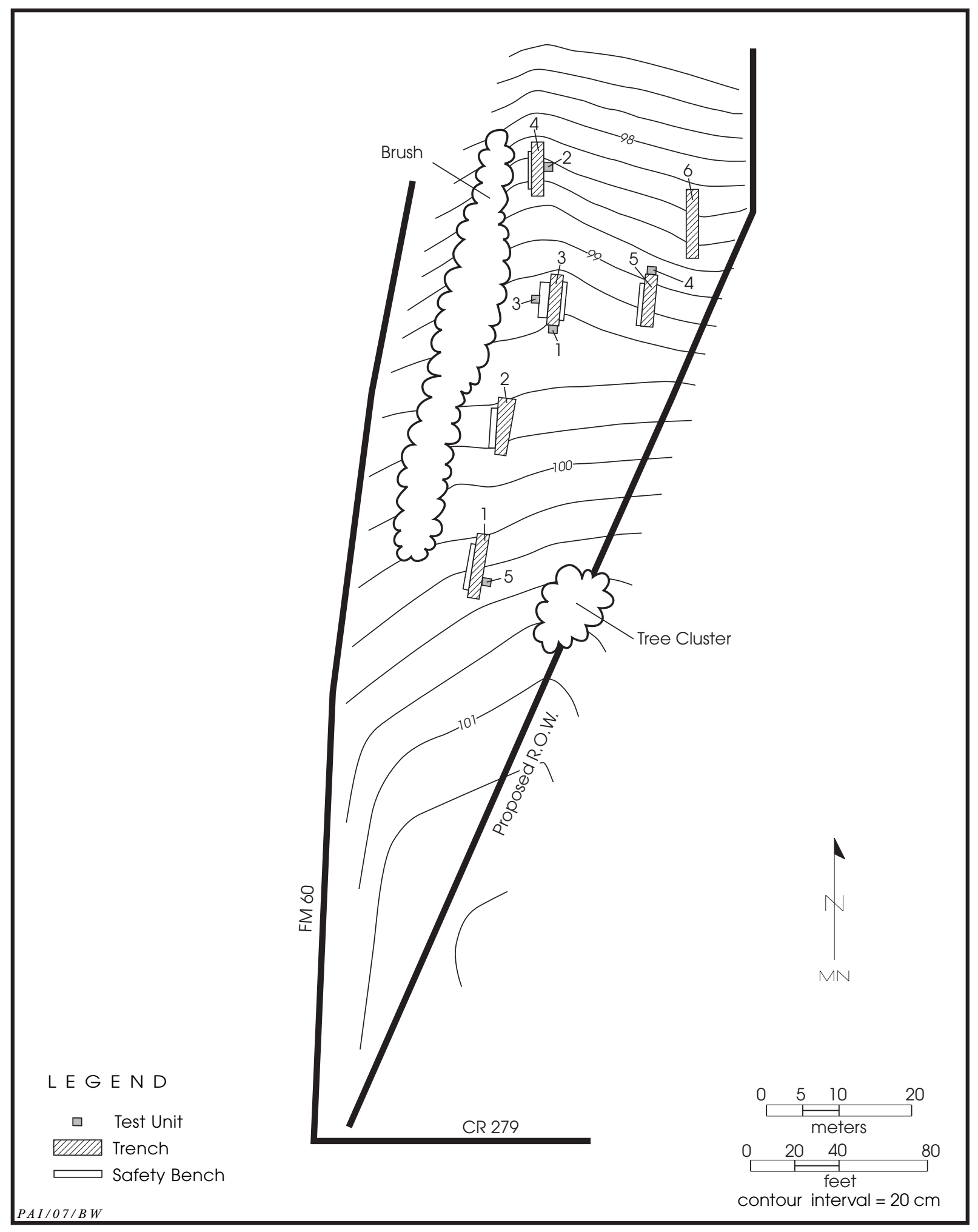

Figure 2. Plan of 41BU75 showing locations of Gradall trenches and test units. 
Trench 6, ca. 5 m northeast of Trench 5 , hit basal clay at $0.60 \mathrm{~m}$. No cultural materials were observed in the walls, and only a thin and faint portion of the paleosol was present. Based on the shallow sand and lack of artifacts, no unit was excavated off of Trench 6 .

These five units revealed that, contrary to what was suggested by the 2002 survey investigations, the archeological remains are not restricted to the upper $1 \mathrm{~m}$. Instead, artifacts were found throughout the sandy mantle, which varies greatly in thickness.

\section{SEDIMENTS AND STRATIGRAPHY}

The ridge upon which $41 B U 75$ rests is mapped as part of an extensive Pleistocene fluvial terrace that extends ca. $15 \mathrm{~km}$ along the west margin of the Brazos River floodplain and is ca. $3 \mathrm{~km}$ wide in the vicinity of the site (Bureau of Economic Geology 1974). The sediments observed in the trenches, however, are more consistent with sandy sediments shed from the Eocene Yegua Formation, which is mapped ca. $2.5 \mathrm{~km}$ to the southwest, than with Pleistocene terrace deposits. Absent from the sandy site deposits are sandy and gravelly fluvial structures and facies that ought to be present if the landform consists of terrace deposits. In any case, the basal red sandy clay that underlies $41 B U 75$ is ancient and not of a culturally relevant age. The sands that mantle the site, and the processes by which those sands have accumulated, are relevant, though, since they contain abundant archeological remains.

Table 1 contains profile descriptions for selected trenches. In most profiles, a thin (18$24 \mathrm{~cm}$ ) deposit of recent colluvium sits atop a brown to dark brown fine sandy loam to loamy sand representing a buried $\mathrm{Ab}$ horizon (Figure 3). This soil is present across most of the site, although it appears darker and thicker in the central portion. It is presumed that the soil formed on a sandy colluvial-slopewash unit that dates mostly to the late Holocene. Underlying the buried soil and the late Holocene sandy mantle is the sandy clay bedrock, usually imprinted with a truncated ancient soil. As noted above, this appears to be of Eocene age. The topography of the bedrock surface does not mimic the topography of the modern ground surface (the sandy mantle varies greatly in thickness), presumably reflecting ancient erosion of the bedrock surface and subsequent accumulation of the overlying sands.

The precise geomorphic processes active in the sandy mantle region of east-central Texas remain a matter of debate. Some argue that the sandy mantle is not a depositional unit at all, but simply in situ ancient deposits freed up by weathering of the sandy bedrock (Brown 1975; Bruseth and Martin 2001). Others have shown convincingly that, at least in places, the sands consist of late Holocene colluvium that has buried archeological sites, sometimes with good integrity and sometimes not (Fields and Klement 1995:54-55; Frederick et al. 2001). Thoms (1993), working on the east wall of the Brazos valley northeast of the current project area, proposed a model that emphasizes pedoturbation, graviturbation, and gullying as agents for burial of archeological materials. Elements of Thoms's model probably apply at 41BU75, as there is ample evidence of turbation of various sorts as well as erosional sculpting of the Eocene bedrock. However, the presence of the paleosol at 41BU75, and a paleosol at 41BU51 nearby (Broehm et al. 2010:15), clearly shows that the sands are depositional. They probably have been transported from the slightly higher upland surfaces to the south and west by colluvial processes and sheetwash.

\section{MATERIALS RECOVERED}

The test excavations did not identify any cultural features, but they did recover a modest sample of artifacts. The collection consists of 6 ceramic sherds, 5 arrow points, 11 other chipped stone tools, 4 cores and tested cobbles, 1,224 pieces of unmodified debitage, 6 ground or battered stone tools, and 44 historic items. Nonartifactual materials recovered consist of burned rocks, unmodified silicified wood, burned clay and daub, faunal remains, and charcoal. Because components cannot be isolated (see Artifact Distributions and Site Components below), the descriptions of these materials below are for the site as a whole rather than for analytical units.

\section{Ceramic Artifacts}

The ceramic vessel sherds are described using the following attributes: vessel part, paste, 
Table 1. Profile descriptions for selected trenches

\begin{tabular}{|c|c|c|}
\hline Trench and Zone & Depth $(\mathrm{cm})$ & Description \\
\hline Trench 1 , Zone 1 & $0-54$ & $\begin{array}{l}\text { Brown ( } 7.5 \text { YR 4/4) very fine loamy sand, very friable, weak fine } \\
\text { blocky subangular structure, common roots and rootlets, many } \\
\text { insect and worm burrow casts, common rodent burrows, gradual } \\
\text { wavy lower boundary. A horizon. }\end{array}$ \\
\hline Trench 1 , Zone 2 & $54-66$ & $\begin{array}{l}\text { Light brown ( } 7.5 Y R \text { 6/4) fine sandy loam, very friable, weak fine } \\
\text { blocky subangular structure, few roots and rootlets, few rodent } \\
\text { burrows, few insect and worm burrow casts, clear smooth lower } \\
\text { boundary. AE horizon. }\end{array}$ \\
\hline Trench 1 , Zone 3 & $66-95$ & $\begin{array}{l}\text { Light yellowish brown (10YR 6/4) fine sandy loam, very friable, } \\
\text { weak fine blocky subangular structure, few rootlets, few rodent } \\
\text { burrows, few insect and worm burrow casts, few sandstone } \\
\text { fragments, abrupt smooth lower boundary. E horizon. }\end{array}$ \\
\hline Trench 1 , Zone 4 & $95+$ & $\begin{array}{l}\text { Mottled red ( } 2.5 \mathrm{YR} 5 / 8) \text { and reddish yellow }(7.5 \mathrm{YR} 6 / 8) \text { sandy clay } \\
\text { loam, strong medium blocky angular structure, lower boundary not } \\
\text { observed. } 2 \text { Bt horizon. }\end{array}$ \\
\hline Trench 3 , Zone 1 & $0-24$ & $\begin{array}{l}\text { Brown ( } 7.5 Y R \text { 4/4) fine sandy loam, friable, weak fine blocky } \\
\text { subangular structure, common roots and rootlets, few insect and } \\
\text { worm burrow casts, abrupt smooth lower boundary. C horizon. }\end{array}$ \\
\hline Trench 3 , Zone 2 & $24-48$ & $\begin{array}{l}\text { Dark brown ( } 7.5 Y R \text { 3/2) fine sandy loam, friable, weak fine blocky } \\
\text { subangular structure, few roots and rootlets, few insect and worm } \\
\text { burrow casts, few clay lamellae ( } 3-5 \mathrm{~mm} \text { thick), clear smooth lower } \\
\text { boundary. Ab horizon. }\end{array}$ \\
\hline Trench 3, Zone 3 & $48-82$ & $\begin{array}{l}\text { Brown (7.5YR 4/3) fine sandy loam, friable, weak fine blocky } \\
\text { subangular structure, few roots and rootlets, few rodent burrows, } \\
\text { few insect and worm burrow casts, few clay lamellae }(4-5 \mathrm{~mm} \\
\text { thick), clear smooth lower boundary. Bb horizon. }\end{array}$ \\
\hline Trench 3 , Zone 4 & $82-150$ & $\begin{array}{l}\text { Brown }(7.5 \mathrm{YR} 5 / 4) \text { fine loamy sand, friable, weak fine blocky } \\
\text { subangular structure, few roots and rootlets, few clay lamellae ( } 2-3 \\
\text { mm thick), lower boundary not observed. C horizon. }\end{array}$ \\
\hline Trench 3 , Zone 5 & $150+$ & $\begin{array}{l}\text { Mottled red ( } 2.5 \mathrm{YR} 5 / 8) \text { and reddish yellow }(7.5 \mathrm{YR} 6 / 8) \text { sandy clay } \\
\text { loam, strong medium blocky angular structure, lower boundary not } \\
\text { observed. } 2 \text { Bt horizon. }\end{array}$ \\
\hline Trench 5, Zone 1 & $0-18$ & $\begin{array}{l}\text { Brown ( } 7.5 \text { YR } 5 / 4) \text { very fine loamy sand, friable, weak fine blocky } \\
\text { subangular structure, common roots and rootlets, clear smooth } \\
\text { lower boundary. C horizon. }\end{array}$ \\
\hline Trench 5, Zone 2 & $18-46$ & $\begin{array}{l}\text { Brown ( } 7.5 \mathrm{YR} 4 / 3) \text { very fine loamy sand, friable, weak fine blocky } \\
\text { subangular structure, common roots and rootlets, few rodent } \\
\text { burrows, many insect and worm burrow casts, clear wavy to broken } \\
\text { lower boundary. Ab horizon. }\end{array}$ \\
\hline Trench 5 , Zone 3 & $46-110$ & $\begin{array}{l}\text { Brown }(7.5 \mathrm{YR} 5 / 4) \text { fine sandy loam, friable, weak fine blocky } \\
\text { subangular structure, common roots and rootlets, common insect } \\
\text { and worm burrow casts, few rodent burrows, few clay lamellae }(<2 \\
\text { mm thick), lower boundary not observed. Bb horizon. }\end{array}$ \\
\hline Trench 5, Zone 4 & $110+$ & $\begin{array}{l}\text { Mottled red ( } 2.5 \mathrm{YR} 5 / 8) \text { and reddish yellow }(7.5 \mathrm{YR} 6 / 8) \text { sandy clay } \\
\text { loam, strong medium blocky angular structure, lower boundary not } \\
\text { observed. } 2 \text { Bt horizon. }\end{array}$ \\
\hline
\end{tabular}




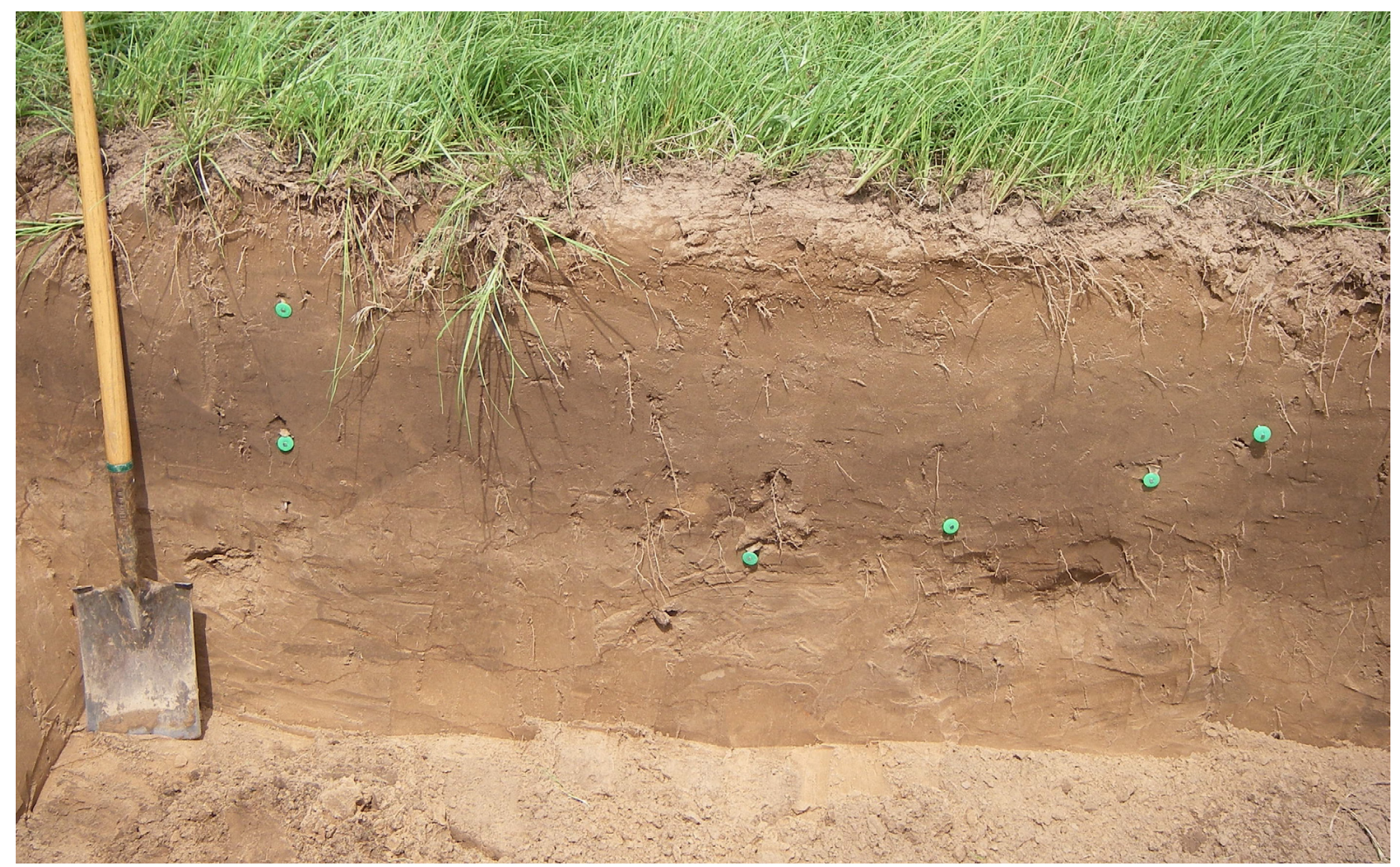

Figure 3. Photograph of the upper ca. $1 \mathrm{~m}$ of the west wall of Trench 3, with buried Ab horizon at 24-48 cm; green tags mark artifacts.

temper, exterior surface finish, interior surface finish, surface color, core color, decoration, size, thickness, rim orientation, lip form, and type. Paste and temper were determined on a fresh break using 10x magnification. Ceramic type was assessed based on the type descriptions presented by Suhm and Jelks (1962).

The six sherds were recovered from Levels 6 to 14 in four different test units, indicating a small and widely dispersed sample (Table 2). They consist of two rims and four body sherds (Figure 4). All are small, ranging from 1.5 to $4.0 \mathrm{~cm}$ in maximum length and 2.14 to $7.52 \mathrm{~mm}$ in thickness. Four have a sandy paste, and two have a clay paste. The sherds with a clay paste are grog tempered, while the sandy paste sherds can be considered sand tempered, although one has both sand and bone temper. Five sherds have smoothed interior surfaces, while the sixth interior is eroded. The latter also has an eroded exterior surface. The other exterior surfaces are smoothed $(\mathrm{n}=3)$, burnished, or eroded. Core color is black on all specimens, while surface colors include gray, very dark gray, pale brown, and dark yellowish brown with at least one undecorated body sherd showing evidence of fire clouding. Both rims have tapered lips; only one is large enough to show that it is an everted rim, probably from a small jar. This everted rim, from Level 7 of Test Unit 4, is one of two sherds that have some exterior decoration. It is incised; a small body sherd displays a single punctation.

Associating most of these sherds with ceramic types is impossible due to their small size and general lack of decoration. The single exception is the incised rim, which displays a broad crosshatched motif consistent with Maydelle Incised, a Middle and Late Caddo jar type that is found commonly across east Texas (Gadus et al. 2001:110-112; Perttula 2013:198-199; Suhm and Jelks 1962:103). The grog temper and clay paste of this sherd, and of one undecorated sherd, support their identification as Caddoan. The other four sherds with sandy pastes and only sand or sand and bone as temper likely represent Goose Creek ware from the upper Texas coast or Early Ceramic/Woodland period sandy paste ware common to southeast Texas (Perttula and Ellis 2013:130). Thus, this small sherd sample suggests that the site has both Early Ceramic/Woodland and Late Prehistoric components. 
Table 2. Attributes of the ceramic vessel sherds

\begin{tabular}{|c|c|c|c|c|c|c|c|c|c|}
\hline Provenience & Part & Paste & Temper & Decoration & Interior & Exterior & $\begin{array}{l}\text { Size } \\
(\mathrm{cm})\end{array}$ & \begin{tabular}{|c|} 
Thickness \\
$(\mathrm{mm})$
\end{tabular} & $\begin{array}{l}\text { Surface } \\
\text { Color }\end{array}$ \\
\hline $\begin{array}{l}\text { TU 1, } \\
\text { Level } 6\end{array}$ & body & sand & $\begin{array}{l}\text { sand and } \\
\text { bone }\end{array}$ & punctated & smoothed & eroded & 2.5 & 4.37 & gray \\
\hline $\begin{array}{l}\text { TU 1, } \\
\text { Level } 14\end{array}$ & body & clay & grog & none & smoothed & smoothed & 3.0 & 7.52 & $\begin{array}{l}\text { pale brown, } \\
\text { gray, very } \\
\text { dark gray }\end{array}$ \\
\hline $\begin{array}{l}\text { TU 2, } \\
\text { Level } 7\end{array}$ & rim & sand & sand & none & smoothed & smoothed & 2.0 & 2.14 & $\begin{array}{l}\text { dark } \\
\text { yellowish } \\
\text { brown }\end{array}$ \\
\hline $\begin{array}{l}\text { TU 3, } \\
\text { Level } 9\end{array}$ & body & sand & sand & none & smoothed & burnished & 1.5 & 3.08 & $\begin{array}{l}\text { very dark } \\
\text { gray }\end{array}$ \\
\hline $\begin{array}{l}\text { TU 3, } \\
\text { Level } 13\end{array}$ & body & sand & sand & none & eroded & eroded & 4.0 & 6.42 & $\begin{array}{l}\text { gray, very } \\
\text { dark gray }\end{array}$ \\
\hline $\begin{array}{l}\text { TU 4, } \\
\text { Level } 7\end{array}$ & rim & clay & grog & incised & smoothed & smoothed & 2.5 & 3.46 & $\begin{array}{l}\text { pale brown, } \\
\text { dark gray }\end{array}$ \\
\hline
\end{tabular}
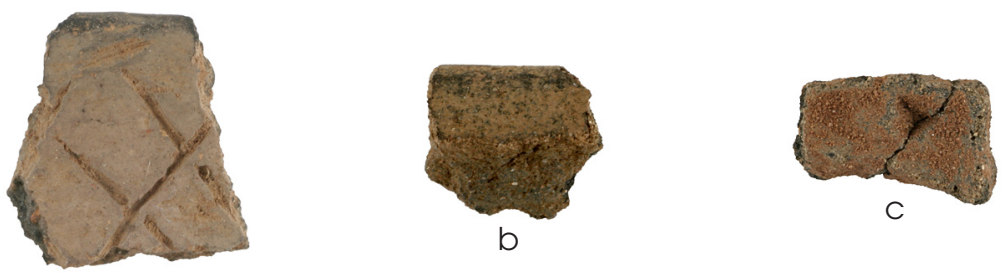

a

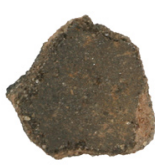

d

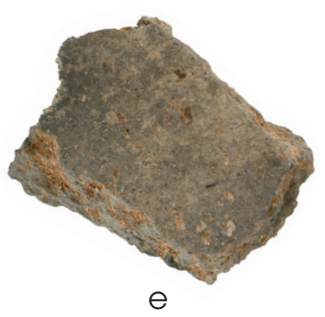

\begin{tabular}{lll}
0 & 1 & 2 \\
\multicolumn{2}{|l|}{} & 1
\end{tabular}

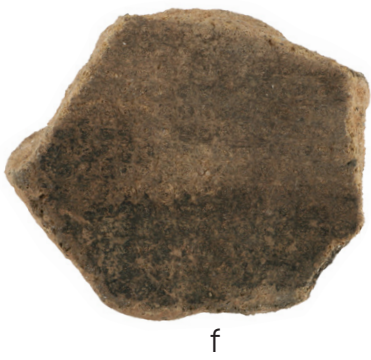

.<smiles>CCC</smiles>

Figure 4. Ceramic sherds recovered. (a) Rim with incised broad crosshatching; (b) undecorated rim; (c) body sherd with one stick punctation; (d-f) undecorated body sherds.

\section{Chipped Stone Artifacts}

\section{Arrow Points}

Four arrow points and one arrow point fragment were recovered (Figure 5a-d). Three are typed as Perdiz, and one is a Scallorn.
The small distal fragment could not be typed. Provenience and metric information are provided in Table 3.

A Perdiz point from Test Unit 1 is complete and manufactured of fine-grained white-gray chert that appears to have been heat treated (Figure 5a). It was made from a flake blank, and 

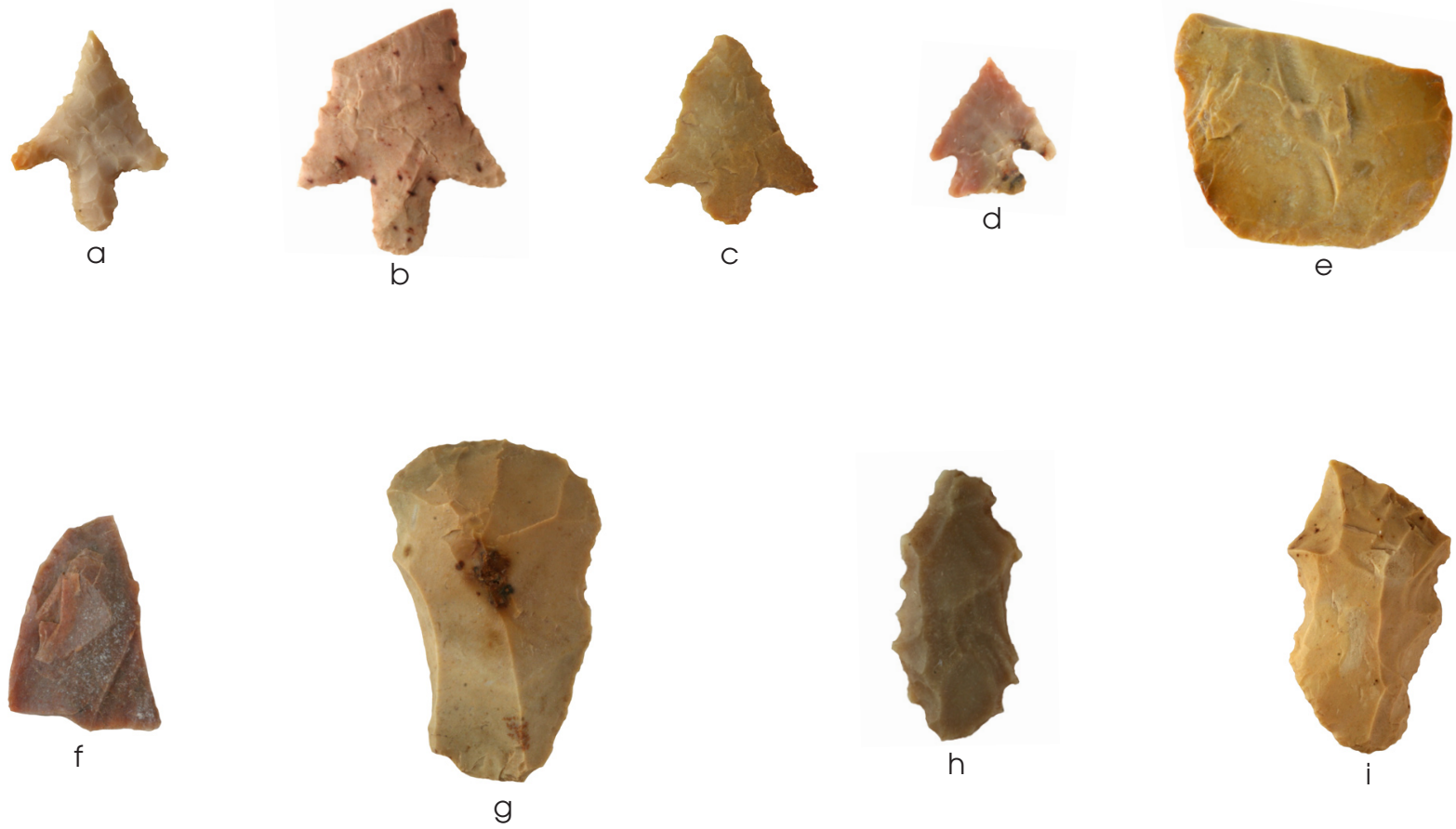

e
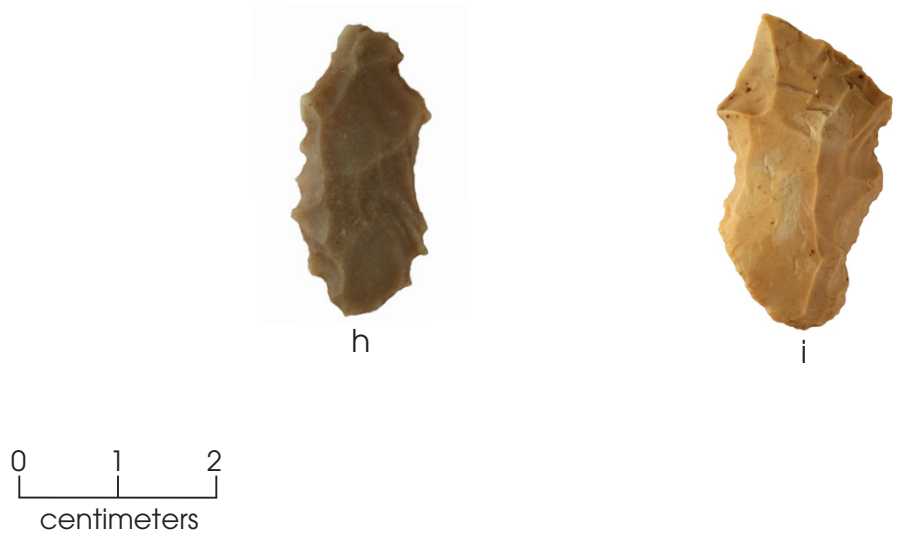

Figure 5. Chipped stone tools recovered. (a-c) Perdiz arrow points; (d) Scallorn arrow point; (e) proximal knife fragment; (f) lateral knife edge fragment; (g) small convex end uniface; (h) serrated flake; (i) serrated or beaked uniface.

part of the ventral surface is still visible. One lateral edge is concave, and the other is slightly recurved. Stem edges are straight, and the basal edge is convex. It weighs $0.6 \mathrm{~g}$.

The second Perdiz point, a proximo-medial fragment from Test Unit 3, was manufactured from heat-treated light yellow or cream-colored chert with small flecks of darker material (Figure 5b). The point snapped midblade in an oblique bending fracture, but the cause of fracture is undetermined. The shoulders are well barbed with straight-angled shoulder edges, straight contracting stem edges, and a convex basal edge. The blade and stem are very thin and very well made by pressure flaking. It weighs $1.3 \mathrm{~g}$.

The third Perdiz point, a complete specimen from Test Unit 4, was manufactured from tan-yellow fine-grained chert that does not appear to have been heat treated (Figure 5c). The shoulders are barbed with concave edges. Both blade edges are recurved by resharpening. One shoulder/barb and the stem also have been reworked. This point weighs $0.8 \mathrm{~g}$.
The Scallorn point, from Test Unit 1, is complete but considerably reworked along both blade edges, with well-executed pressure flaking (Figure 5d). The raw material is heat-treated tan chert. It weighs $0.8 \mathrm{~g}$.

The small distal arrow point fragment, from Test Unit 1, is of heat-treated brown chert. The blade edges and surface are finished with wellcontrolled pressure flaking and a needle-sharp tip. The blade was broken in an oblique bending fracture, perhaps related to impact.

\section{Bifaces}

Four biface fragments were recovered. Two distal fragments are from Test Unit 1, Levels 4 and 8 , and each was manufactured from heat-treated chert. The fragment from Level 4 is a gray-blue fine-grained chert resembling Georgetown chert and is a very thin pressureflaked blade segment. Irregular and unfinished lateral edges suggest that the biface was broken early in manufacture. It is $3.05 \mathrm{~mm}$ thick. The fragment from Level 8 appears to be from a 
Table 3. Provenience and metric data for the arrow points (measurements in $\mathbf{m m}$ )

\begin{tabular}{|c|c|c|c|c|c|c|c|c|c|}
\hline Provenience & है & 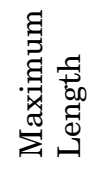 & 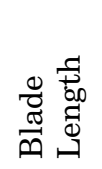 & 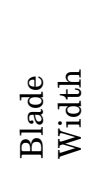 & 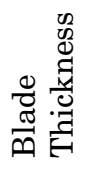 & 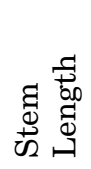 & 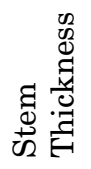 & 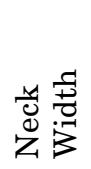 & 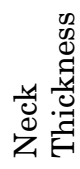 \\
\hline TU 1, Level 3 & Perdiz & 21.93 & 16.40 & 17.22 & 2.64 & 5.58 & 1.76 & 5.22 & 1.78 \\
\hline TU 3, Level 4 & Perdiz & - & - & 22.92 & 2.83 & 8.86 & 1.91 & 7.09 & 2.44 \\
\hline TU 4, Level 4 & Perdiz & 20.78 & 16.68 & 18.87 & 3.43 & 4.1 & 1.4 & 5.78 & 2.08 \\
\hline TU 1, Level 1 & Scallorn & 15.37 & 11.27 & 13.94 & 2.21 & 4.1 & 2.16 & 6.13 & 2.64 \\
\hline TU 1, Level 6 & Untyped & - & - & - & 2.04 & - & - & - & - \\
\hline
\end{tabular}

larger finished biface; it is $5.80 \mathrm{~mm}$ thick. A basal fragment from Test Unit 1, Level 12, is a proximal portion of a knife manufactured of heat-treated yellow chert (Figure 5e). The basal edge is convex and lightly ground, and the remaining lateral edge portions are straight to slightly convex. Soft-hammer percussion scars meet along the midline of the biface on both faces. The knife was broken by an obliquely oriented bending fracture during manufacture. It is $29.94 \mathrm{~mm}$ wide and $5.31 \mathrm{~mm}$ thick. The fourth biface is a lateral edge portion of a probable knife from Test Unit 3, Level 6 (Figure 5f). It was broken by thermal fracture and an oblique bending fracture. The chert is dark purplish brown, probably from burning. It is $5.90 \mathrm{~mm}$ thick.

\section{Unifaces}

Three retouched flakes or unifaces were recovered. Table 4 provides provenience and metric data. A specimen from Test Unit 2 resembles a small convex end scraper manufactured from a percussion flake (Figure 5g). The proximal end and striking platform are intact. The raw material is tan-gray fine-grained chert. The convex distal end has been shaped by light soft-hammer percussion and pressure flaking. The pressure flaking is bifacial along a portion of the edge and may have been done to finish and shape the edge. The other two unifaces are retouched flakes from Test Unit 3 (Figure $5 \mathrm{~h}-\mathrm{i}$ ). The one from Level 6 is a narrow bladelike percussion flake of gray finegrained chert. Both lateral edges have a serrated or denticulate appearance created by pressure flaking. The specimen from Level 7 is a small percussion flake or trimmed flake fragment of light yellowish tan fine-grained chert. The edges have been trimmed by edge nibbling or marginal pressure flaking, which gives the artifact a serrated edge or beaked tool appearance.

\section{Edge-Modified Flakes}

Provenience and metric data for the four edge-modified flakes are provided in Table 4. These tools were distinguished from unmodified flakes based on the presence of microscopically visible patterned microflaking damage from tool use along one or more edges or tool portions. The presence of similar patina over the edge damage as on the dorsal and ventral surfaces of the flakes rules out the possibility that the microflaking was produced during screening or excavation recovery. The raw materials for all four tools are locally available fine-grained cherts in various shades of yellowish brown. All pieces retain some brown

Table 4. Provenience and metric data for unifaces and edge-modified flakes (measurements in $\mathbf{m m}$ )

\begin{tabular}{l|l|c|c|c}
\hline \multicolumn{1}{c|}{ Provenience } & \multicolumn{1}{|c|}{ Tool Type } & $\begin{array}{c}\text { Maximum } \\
\text { Length }\end{array}$ & Maximum Width & $\begin{array}{c}\text { Maximum } \\
\text { Thickness }\end{array}$ \\
\hline TU 2, Level 9 & Uniface & 37.44 & 23.00 & 6.97 \\
\hline TU 3, Level 6 & Uniface & 29.98 & 14.12 & 2.55 \\
\hline TU 3, Level 7 & Uniface & 31.94 & 17.99 & 6.68 \\
\hline TU 1, Level 15 & Edge-modified flake & 20.27 & 27.89 & 4.68 \\
\hline TU 2, Level 16 & Edge-modified flake & 52.13 & 23.38 & 9.45 \\
\hline TU 3, Level 7 & Edge-modified flake & 32.14 & 32.82 & 5.76 \\
\hline TU 5, Level 9 & Edge-modified flake & 36.27 & 39.13 & 6.83 \\
\hline
\end{tabular}


stream-worn dorsal cortex, and none have been heat treated. Three are complete percussion flakes, and one is a medial flake fragment. Edge damage patterns are characteristic of scraping and cutting tasks.

\section{Cores and Tested Cobbles}

Provenience and metric data for the three cores and one tested cobble are provided in Table 5 . The cores are chert cobble raw materials that are commonly available on the gravel bars of the Brazos River and tributary streams and in terrace deposits. Colors vary from yellowish brown to mottled gray/brown. One core recovered from Trench 5 is a cobble that fractured along an internal flaw and has remnant flake scars on one side. A multidirectional core on a cortical percussion flake was recovered from Test Unit 3 ; a portion of the striking platform and ventral surface are still present, and the dorsal side has brown stream-worn cortex. A core from Test Unit 2 is the proximal remnant of a hard-hammer percussion flake. Remnants of the cortex platform and ventral surface are present. This is a bidirectional core with striking platforms on opposite ends of the piece. No platform preparation is evident on any of the cores or the tested cobble. The tested cobble is an elongate oval, flat pebble that has a percussion flake scar on one end and four small flake scars on the opposite end. It may have been selected to manufacture a small biface, as it is too small to have produced percussion flakes large enough to use for tools. It is of light yellow chert with a thin zone of brown beneath white stream-worn cortex.

\section{Unmodified Debitage}

A total of 1,224 pieces of chipped stone debitage was recovered. Given the inability to isolate discrete spatial and temporal components at the site, a detailed analysis of the debitage was considered unwarranted. However, all debitage was sorted and examined to make sure that all cores, tools, tool fragments, and edge-modified tools (including utilized but unretouched flakes) had been pulled for analysis.

Observations made during sorting indicate that all of the debitage is from locally available cobbles and pebbles of chert, quartzite, and occasional pieces of petrified wood, as are all the chipped stone tools and cores. These materials are easily procured from alluvial terrace deposits, exposed gravel sources, and gravel bars in the Brazos River and adjacent tributary streams. The cherts occur in various shades of brown, yellow, gray, and red. The presence of percussion flakes, common specimens with stream-worn cortex, and shatter indicate that primary reduction of chert cobbles procured from alluvial gravel deposits was conducted at the site. Also, some of the debitage is heat treated, indicating that it was removed from heat-treated tool blanks or flakes or from formal tools. The debitage is very comparable to materials recovered at 41BU51 not far to the north (Broehm et al. 2010).

\section{Ground and Battered Stones}

Six stone artifacts modified by grinding or battering were recovered. One is a fragment of a tabular grinding slab, one is a pigment source, and four are hammerstones (three fragmentary and one complete). The grinding slab, from Level 5 of Test Unit 1, is gray coarse-grained sandstone with smoothing on both surfaces. The pigment source, from Level 5 of Test Unit 4 , is a grayish siltstone that has been abraded and ground smooth on all faces and has faint striations on one face. All of the hammerstones are quartzite pebbles or pebble/cobble fragments with varying amounts of battering. The presence of hammerstones corresponds with the indications of hard-hammer percussion and early-stage core reduction represented in the debitage and few cores.

Table 5. Provenience and metric data for cores and tested cobble (measurements in mm; weights in grams)

\begin{tabular}{l|l|c|c|c|c}
\multicolumn{1}{c|}{ Provenience } & \multicolumn{1}{|c|}{ Core Type } & Length & Width & Thickness & Weight \\
\hline TU 2, Level 18 & Bidirectional & 38.49 & 36.60 & 20.45 & 36.7 \\
\hline TU 3, Level 8 & Multidirectional & 63.13 & 40.62 & 24.11 & 48.6 \\
\hline Trench 5, 102 cm & Unidirectional fragment & 54.21 & 46.43 & 28.21 & 75.1 \\
\hline TU 3, Level 7 & Tested cobble & 57.16 & 33.04 & 14.00 & 24.4 \\
\hline
\end{tabular}




\section{Burned Rocks}

Very few burned rocks were observed at 41BU75. Just four small fragments of burned cobble chert were found in Test Unit 2 (Levels 10, 14, and 17) and Test Unit 5 (Level 7). These were encountered as isolated pieces and not as parts of features. Their paucity suggests that rock cooking features were used infrequently, if at all, during occupations at the site. ${ }^{2}$

\section{Unmodified Silicified Wood}

Five pieces of unmodified silicified wood were recovered in Levels 2 and 17 of Test Unit 2, Level 5 of Test Unit 3, and Level 11 of Test Unit $5(\mathrm{n}=2)$. These items likely were introduced into the deposits as a result of the prehistoric occupations, but their functions are unknown.

\section{Faunal Remains}

Faunal remains consist of 50 pieces of animal bone and 1 small piece of freshwater mussel shell. A total of $42.5 \mathrm{~g}$ of bone and $0.1 \mathrm{~g}$ of mussel shell were recovered from 13 proveniences. Most of the bones are highly fragmented, poorly preserved, and not identifiable to species, but none of the remains suggest animals larger than deer. Seven pieces are burned, based on color changes and surface cracking. Although the majority display weathering, cracks, and postdepositional breakage, 4 small fragments from Level 13 of Test Unit 2 exhibit fractures reminiscent of green bone breakage and spiral fracturing of fresh bone.

One specimen (broken in two pieces), from Level 11 of Test Unit 3, appears to have been worked and may represent a fragment of a bone pin or awl shaft (Figure 6). The cross section is plano-convex, and the surfaces, although weathered and cracked, appear to have been ground smooth and deliberately shaped. It appears to have been manufactured from a bone splinter rather than a complete shaft element.

\section{Burned Clay or Daub}

Burned clay or daub was relatively abundant, totaling $447.6 \mathrm{~g}$ from 22 proveniences.

2 The recovery of burned rocks in recent testing west of FM 60 suggests that rock cooking was done in that part of the site (Barrett and Abbott 2013).

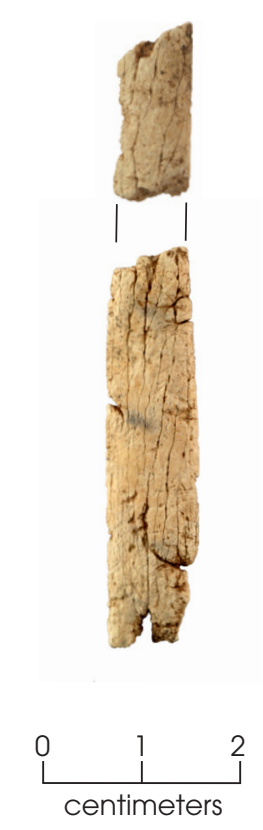

Figure 6. Worked bone awl or pin.

It was especially common in Test Units 2 and 3 . Although many pieces are small, $1-2 \mathrm{~cm}$ or less, a few are $4-6 \mathrm{~cm}$ in maximum dimension and retain wattle impressions in their surfaces, indicating that they likely represent burned structural remains (Figure 7). Some pieces also exhibit well-burned and blackened cores. Burned clay or daub was recovered throughout the deposits rather than as discrete concentrations or features. This material was also abundant at 41BU51 (Broehm et al. 2010:49).

\section{Charcoal}

A total of $32.3 \mathrm{~g}$ of charcoal was recovered from 19 proveniences in Test Units 2, 3, and 4, primarily from the middle and lower levels. All of it was recovered during screening rather than as discrete features. Most of it is wood, much of which appeared fresh and may be related to historic burning rather than to prehistoric occupation. However, recognizable burned nutshell, which probably would not occur naturally in this setting and thus almost certainly is prehistoric, was recovered from Level 10 of Test Unit 3.

\section{Historic Artifacts}

Forty-five historic artifacts were recovered in the excavations. These consist of 3 nails, 1 

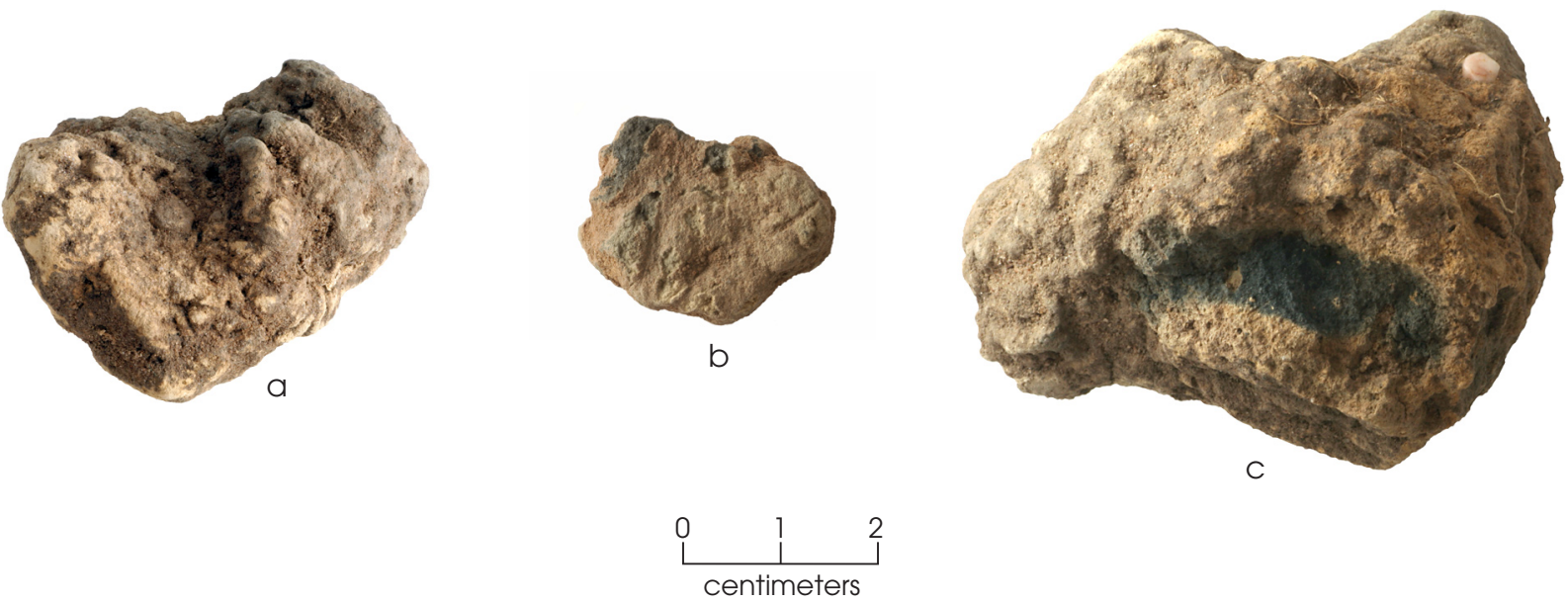

Figure 7. Daub. (a) Fragment with large U-shaped stick(?) impression; (b) fragment with small grass(?) impressions; (c) large nodule with oxidized outer surface and blackened core.

shotgun shell base, 16 pieces of unidentified metal, 22 pieces of glass (clear, amber, solarized purple, cobalt blue, and light green), 1 milk glass sherd, 1 stoneware sherd, and 1 brick fragment. They were recovered from eight proveniences, all between Levels 1 and 5, in Test Units 1, 3, 4 and 5 . This vertical distribution reflects mixing by bioturbation and plowing. This small assemblage seems too diverse to reflect simply roadside trash. Rather, it suggest that a structure stood on or near the site sometime during the first half of the twentieth century.

The nails, although badly corroded, are the round wire type. The headstamp on the shotgun shell base reads "Peters....No. 9.....New Victor." The No. 9 refers to the size of shot contained in the shell. Dates for manufacture of Peters New Victor shells are between 1897 and 1935 (Vinson 1968:91). The head is brass, but the primer cup is corroded and appears to be steel. The outside of the brass base has a line circling it with hatched lines beneath it. This type of marking could date between 1924 and 1932 (http://www.headstamps. x10.mx/peters.html, accessed 8/6/13).

\section{ARTIFACT DISTRIBUTIONS AND SITE COMPONENTS}

Artifacts (i.e., prehistoric ceramic sherds and chipped and ground or battered stones) were found in all of the test units and were especially abundant in Test Unit $1(\mathrm{n}=314)$, Test Unit $2(\mathrm{n}=306)$, and Test Unit $3(\mathrm{n}=413)$, which occupy the crest of a slight north-southtrending rise on the terrace surface (Table 6).
This suggests that Native American occupation of the site occurred most consistently in this area. Artifacts were moderately abundant in Test Unit $4(\mathrm{n}=178)$ to the east, and the site certainly extends beyond the proposed right of way in this direction. To the west, the site has been truncated by FM 60. Downslope to the north beyond Test Unit 2, the site is bounded by a swale associated with an ephemeral drainage that runs north to Old River. Artifacts were least numerous in Test Unit $5(\mathrm{n}=44)$, and thus the cultural deposit diminishes upslope to the south where County Road 279 cuts across the terrace. Nonartifactual cultural materials have distributions that are similar to the artifacts but not identical. For example, Test Unit 2 yielded most of the burned clay/daub (66 percent), faunal remains (75 percent), and charcoal (69 percent), while Test Units 1 and 3, with comparable or higher artifact counts, had just 11 and 21 percent (burned clay/daub), 4 and 16 percent (faunal remains), and 0 and 19 percent (charcoal). Test Unit 4 had even smaller quantities, and Test Unit 5 had none. Another thing that distinguishes Test Unit 5 is that it contained almost all (91 percent) of the historic artifacts, implying that the early- to mid-twentieth century occupation that left those artifacts was upslope from the site to the south.

Vertically, artifacts occur throughout the Holocene sandy mantle, regardless of its thickness (see Table 6). Artifacts do decrease in frequency below certain depths, however. In Test Units 1 and 4, artifact densities are high from the surface to $70-80 \mathrm{~cm}$. Test Units 2 
Table 6. Artifacts by provenience

\begin{tabular}{|c|c|c|c|c|c|c|c|c|c|c|}
\hline $\mathrm{TU}$ & Level & $\begin{array}{c}\text { Ceramic } \\
\text { Sherd } \\
\end{array}$ & $\begin{array}{c}\text { Lithic } \\
\text { Tool } \\
\end{array}$ & $\begin{array}{c}\text { Core/ } \\
\text { Tested } \\
\text { Cobble }\end{array}$ & Debitage & $\begin{array}{c}\text { Ground/ } \\
\text { Battered } \\
\text { Stone } \\
\end{array}$ & $\begin{array}{l}\text { Burned } \\
\text { Clay (g) }\end{array}$ & $\begin{array}{l}\text { Bone/ } \\
\text { Shell } \\
\end{array}$ & $\begin{array}{c}\text { Charcoal } \\
(\mathrm{g})\end{array}$ & Historic \\
\hline 1 & 1 & & 1 & & 14 & & & & & \\
\hline 1 & 2 & & & & 36 & & & & & \\
\hline 1 & 3 & & 1 & & 22 & & & & & \\
\hline 1 & 4 & & & & 62 & & & & & \\
\hline 1 & 5 & & 1 & & 40 & 1 & & 2 & & 1 \\
\hline 1 & 6 & 1 & 1 & & 41 & & & & & \\
\hline 1 & 7 & & & & 21 & & & & & \\
\hline 1 & 8 & & 1 & & 31 & & & & & \\
\hline 1 & 9 & & & & 8 & & 47.8 & & & \\
\hline 1 & 10 & & & & 6 & & & & & \\
\hline 1 & 11 & & & & 6 & & & & & \\
\hline 1 & 12 & & 1 & & 6 & & & & & \\
\hline 1 & 13 & & & & 6 & & & & & \\
\hline 1 & 14 & 1 & & & 4 & & & & & \\
\hline 1 & 15 & & 1 & & 1 & & & & & \\
\hline 2 & 1 & & & & 0 & & & & & \\
\hline 2 & 2 & & & & 14 & & 0.3 & & & \\
\hline 2 & 3 & & & & 22 & & & & 13.1 & \\
\hline 2 & 4 & & & & 19 & & 77.5 & & & \\
\hline 2 & 5 & & & & 27 & & 2.9 & 2 & 0.8 & \\
\hline 2 & 6 & & & & 18 & & 1.9 & & & \\
\hline 2 & 7 & 1 & & & 29 & & 22.0 & 9 & 1.1 & \\
\hline 2 & 8 & & & & 23 & & 12.0 & 1 & 1.1 & \\
\hline 2 & 9 & & 1 & & 30 & & 12.1 & 6 & 1.8 & \\
\hline 2 & 10 & & & & 25 & & 36.7 & & & \\
\hline 2 & 11 & & & & 17 & 1 & 1.3 & 1 & & \\
\hline 2 & 12 & & & & 12 & & 58.4 & & & \\
\hline 2 & 13 & & & & 4 & & 46.1 & 8 & & \\
\hline 2 & 14 & & & & 5 & & 23.3 & & & \\
\hline 2 & 15 & & & & 5 & 2 & & & & \\
\hline 2 & 16 & & 1 & & 15 & & & 11 & 4.4 & \\
\hline 2 & 17 & & & & 10 & & & & & \\
\hline 2 & 18 & & & 1 & 5 & & & & & \\
\hline 2 & 19 & & & & 5 & & & & & \\
\hline 2 & 20 & & & & 13 & 1 & & & & \\
\hline 3 & 1 & & & & 18 & & & & & 2 \\
\hline 3 & 2 & & & & 29 & & & & & \\
\hline 3 & 3 & & & & 26 & & 22.0 & & 2.2 & \\
\hline 3 & 4 & & 1 & & 55 & & & & & \\
\hline 3 & 5 & & & & 47 & & 4.6 & & 0.7 & \\
\hline 3 & 6 & & 2 & & 52 & & & & 0.3 & \\
\hline 3 & 7 & & 2 & 1 & 44 & & 19.1 & 2 & 0.5 & \\
\hline 3 & 8 & & & 1 & 34 & & 14.3 & 1 & 0.9 & \\
\hline 3 & 9 & 1 & & & 33 & & 7.4 & & & \\
\hline 3 & 10 & & & & 32 & & & & 1.4 & \\
\hline
\end{tabular}


Table 6, continued

\begin{tabular}{c|c|c|c|c|c|r|r|r|r|r}
\hline TU & Level & $\begin{array}{c}\text { Ceramic } \\
\text { Sherd }\end{array}$ & $\begin{array}{c}\text { Lithic } \\
\text { Tool }\end{array}$ & $\begin{array}{c}\text { Core/ } \\
\text { Tested } \\
\text { Cobble }\end{array}$ & $\begin{array}{c}\text { Debitage } \\
\text { Battered } \\
\text { Stone }\end{array}$ & $\begin{array}{c}\text { Burned } \\
\text { Clay (g) }\end{array}$ & $\begin{array}{c}\text { Bone/ } \\
\text { Shell }\end{array}$ & $\begin{array}{c}\text { Charcoal } \\
\text { (g) }\end{array}$ & Historic \\
\hline 3 & 11 & & & & 15 & & 6.9 & 2 & & \\
\hline 3 & 12 & & & & 10 & & 16.6 & & & \\
\hline 3 & 14 & 1 & & & 6 & & 3.1 & & & \\
\hline 3 & 15 & & & & 1 & & & & & \\
\hline 4 & 1 & & & & 20 & & & & & \\
\hline 4 & 2 & & & & 24 & & & & & \\
\hline 4 & 3 & & & & 28 & & & & 0.3 & \\
\hline 4 & 4 & & 1 & & 28 & & & & 0.3 & \\
\hline 4 & 5 & & & & 17 & 1 & & & 0.7 & \\
\hline 4 & 6 & & & & 10 & & & & 0.4 & \\
\hline 4 & 7 & 1 & & & 21 & & & 3 & 0.5 & \\
\hline 4 & 8 & & & & 6 & & 11.3 & & 1.0 & \\
\hline 4 & 9 & & & & 9 & & & & 0.8 & \\
\hline 4 & 10 & & & & 11 & & & & & 1 \\
\hline 4 & 11 & & & & 1 & & & & & \\
\hline 5 & 1 & & & & 3 & & & & & 9 \\
\hline 5 & 2 & & & & 13 & & & & & 18 \\
\hline 5 & 3 & & & & 7 & & & & & 7 \\
\hline 5 & 4 & & & & 5 & & & & & 2 \\
\hline 5 & 5 & & & & 4 & & & & & 3 \\
\hline 5 & 6 & & & & 2 & & & & & 2 \\
\hline 5 & 7 & & & & 2 & & & & & \\
\hline 5 & 8 & & & & 5 & & & & & \\
\hline 5 & 9 & & 1 & & 2 & & & & & \\
\hline Trench 5 & & & & 1 & & & & & & \\
\hline
\end{tabular}

and 3 have moderate to high densities down to 100-120 cm, with Test Unit 2 having secondary density peaks at $150-170 \mathrm{~cm}$ and $190-200 \mathrm{~cm}$. The relatively sparse artifacts in Test Unit 5 are most concentrated in the upper sands at $10-20 \mathrm{~cm}$. Combining all five units, densities are consistently high (170-342/m3) at 10-100 cm, with the highest density at $30-40 \mathrm{~cm}$ (Figure 8). Densities below $100 \mathrm{~cm}$ are lower, although the secondary peaks at $150-160$ and $190-200 \mathrm{~cm}$ are notable. Given that the sandy mantle here is a Holocene depositional unit, this distribution suggests that Native Americans occupied the site often over a lengthy time span, with the most intensive or frequent occupations occurring late in the site's history. The only class of nonartifactual remains abundant enough to be shown on Figure 8 is burned clay/daub. It has variable densities at $10-140 \mathrm{~cm}$, with the highest peak at $120 \mathrm{~cm}$, below the highest artifact densities. Faunal remains are distributed between 40 and $160 \mathrm{~cm}$, and charcoal occurs between 20 and $170 \mathrm{~cm}$. These distributions suggest that each of these class of remains relates to multiple occupations.

All five arrow points were found in the upper $60 \mathrm{~cm}$ of the deposits. The Scallorn point is from $0-10 \mathrm{~cm}$ in Test Unit 1, the Perdiz points are from $20-30 \mathrm{~cm}$ in Test Units 1 and 3 and $30-40 \mathrm{~cm}$ in Test Unit 4, and the untyped distal fragment is from $50-60 \mathrm{~cm}$ in Test Unit 1 . The ceramic sherds generally came from deeper. The four sandy-paste sherds are from $50-60 \mathrm{~cm}$ in Test Unit 1, 60-70 $\mathrm{cm}$ in Test Unit 2, and 80-90 


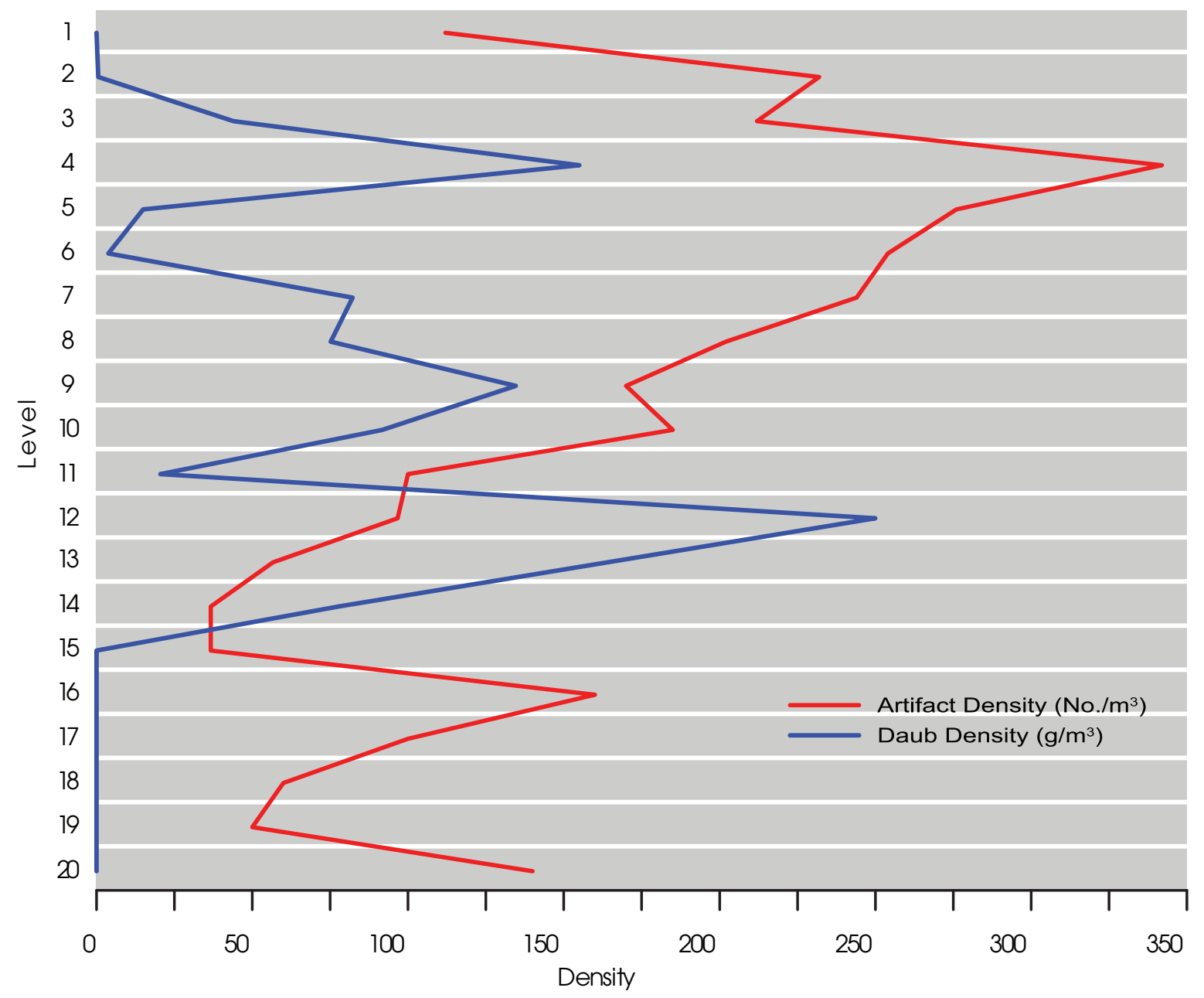

Figure 8. Graphs of artifact and burned clay/daub densities by depth in the test units.

and $120-130 \mathrm{~cm}$ in Test Unit 3 ; the two claypaste sherds are from $60-70 \mathrm{~cm}$ in Test Unit 4 and $130-140 \mathrm{~cm}$ in Test Unit 1.

The co-occurrence of Scallorn and Perdiz points could suggest that at least the upper $40 \mathrm{~cm}$ of the site dates to A.D. 1100-1300, since points of these types were found together in contexts dating to this interval at the J. B. White site (41MM341) in Milam County about $65 \mathrm{~km}$ northwest of 41BU75 (Gadus et al. 2006:138139). Alternatively, these points could indicate that materials representing occupations during both the early and middle-late parts of the Late Prehistoric period are present and simply mixed together. Chronologically assessing the deeper deposits at the site is harder because temporally sensitive artifacts (i.e., ceramics) are few and not all that diagnostic. The absence of dart points suggests that all the cultural deposits could date to the Late Prehistoric period, and this would be supported by the distribution of the two claypaste sherds (at 60-70 and 130-140 cm), which arguably relate to Late Prehistoric Caddo wares from east Texas. The four sandy paste sherds are not much help in resolving this issue, since their affiliations are unknown. They could indicate occupations during the terminal Archaic (i.e., Early Ceramic/Woodland) or Late Prehistoric periods, or both. Their recovery at depths greater than the arrow points would suggest that they relate to terminal Archaic occupations, but their co-occurrence with clay-paste ceramics argues against this. Finally, the recovery of numerous dart points from 41BU51 in a similar geomorphic setting on the same landform nearby suggests that the lower sands at $41 \mathrm{BU} 75$ could contain materials of Archaic age, with the absence of dart points in the collection reported here simply 
being a sampling problem. The recovery of two dart points (typed as Travis and Kent) from the part of 41BU75 west of FM 60 during recent testing by TxDOT supports this interpretation (Barrett and Abbott 2013).

\section{ASSESSMENT AND RECOMMENDATIONS}

While 41BU75 is moderately rich in artifacts (especially lithic debitage) and contains materials suggestive of intensive occupation by Native Americans (especially burned clay perhaps representing wattle-impressed daub), it appears to have a limited capacity to contribute important information. The foremost reason for this is the difficulty of identifying and isolating discrete components, which would make it impossible to draw confident, meaningful interpretations about the behaviors that created the archeological deposits. The difficulty of identifying and isolating components stems from the following characteristics: (1) based on the diagnostic artifacts recovered and their distributions, it is uncertain how many components are present; (2) the site apparently lacks, perhaps because of extensive bioturbation, the kinds of cultural features, such as hearths and pits, that would allow living surfaces or cultural zones to be identified; (3) the bulk of the culturally relevant deposits lack well-defined stratigraphy that could help sort the archeological remains into useful analytical units; (4) the deposits are sandy, poorly consolidated, and obviously disturbed by rodent burrowing and other factors, increasing the potential that artifacts have moved both horizontally and vertically; and (5) artifacts occur in moderate to high densities vertically throughout much of the deposits, with no indications in their distributions that temporally discrete components could be isolated. The fact that the highest artifact frequencies in the four most-productive units occur at varying depths (Level 4 in Test Unit 1, Levels 8 and 10 in Test Unit 2, Levels $5-8$ in Test Unit 3, and Levels 3 and 4 in Test Unit 4) indicates that artifact densities would not provide a good basis for making correlations from unit to unit, supporting the conclusion that isolation of discrete components would be problematical. Given these characteristics, the cultural deposits are considered to have poor integrity of location, design, feeling, and association while retaining some integrity of setting, materials, and workmanship (36 CFR 60.4).

Two other factors also argue that the site has a limited capacity to contribute important information. First, charcoal is poorly preserved (with some probably being modern intrusions), indicating that materials suitable for radiocarbon dating to establish a firm chronology for the site are scarce, especially in the absence of discrete contexts such as features from which to obtain dating samples; macrobotanical remains other than wood charcoal, which would provide information on subsistence resources used, also are sparse. Second, while some identifiable faunal remains are present, most of the animal bones are poorly preserved, small fragments that are not identifiable, thus limiting the amount of subsistence data that could be gained.

For the reasons listed above, 41BU75 is considered to lack important information and thus be ineligible for listing in the National Register of Historic Places under Criterion D (36 CFR 60.4; 36 CFR 800.4, 5) or designation as a State Historical Landmark (13 TAC 26.2, 8). Hence, it is recommended that no further work is warranted. 


\section{REFERENCES CITED}

Barrett, J. W., and J. Abbott

2013 Report for Archeological Survey, CSJ 0648-03-050, FM 60, Burleson County, Bryan District. Texas Department of Transportation, Environmental Affairs Division, Archeological Studies Branch, Austin.

Bement, Leland C., Wayne Bartholomew, Glenn T. Goode, Stephen A. Hall, and David G. Robinson

1989 Excavations at 41BP19, The Kennedy Bluffs Site, Bastrop County, Texas. Contract Reports in Archaeology, Report Number 5. Texas State Department of Highways and Public Transportation, Highway Design Division, Austin.

Blair, W. Frank

1950 The Biotic Provinces of Texas. The Texas Journal of Science 2(1):93-117.

Bolton, Herbert Eugene

1970 Texas in the Middle Eighteenth Century: Studies in Spanish Colonial History and Administration. The Texas State Historical Association and University of Texas Press, Austin.

Bowman, Bradley F.

1985 Winnie's Mound (41BU17): A Case Study in the Prehistory of Burleson County, Texas. Bulletin of the Texas Archeological Society 56:39-74.

Broehm, Cory J., Jennifer K. McWilliams, Ross C. Fields, and Karl W. Kibler

2010 Testing and Data Recovery Excavations at 41BU51, Burleson County, Texas. Archeological Studies Program, Report No. 124. Environmental Affairs Division, Texas Department of Transportation, Austin. Report of Investigations No. 161. Prewitt and Associates, Inc., Austin.

Brown, Ken

1975 Time's Arrow and Postdepositional Disturbance. Paper presented at the 1975 Caddo Conference, College Station, Texas.
Bruseth, James E., and William A. Martin

2001 OSL Dating and Sandy Mantle Sites in East Texas. Current Archeology in Texas $3(1): 12-17$.

Bruseth, James E., and William A. Martin (editors) 1987 The Bird Point Island and Adams Ranch Sites: Methodological and Theoretical Contributions to North Central Texas Archaeology. Richland Creek Technical Series, Vol. II. Archaeology Research Program, Institute for the Study of Earth and Man, Southern Methodist University, Dallas.

Bureau of Economic Geology

1974 Geologic Atlas of Texas, Austin Sheet. Bureau of Economic Geology, The University of Texas at Austin.

Campbell, T. N.

1988 Indians of Southern Texas and Northeastern Mexico: Selected Writings of Thomas Nolan Campbell. Texas Archeological Research Laboratory, with the cooperation of the Department of Anthropology, the College of Liberal Arts, and the Institute of Latin American Studies, The University of Texas at Austin.

Carlson, David L., D. Gentry Steele, and A. G. Comuzzie

1984 Mammoth Excavations at the DuewallNewberry Site on the Brazos River in Texas, 1983. Current Research in the Pleistocene 1:63-64.

Chilton II, Earl W.

1997 Freshwater Fishes of Texas. Texas Parks and Wildlife Press, Austin.

Davis, Michael W., Dan K. Utley, Steve A. Tomka, and Solveig A. Turpin

1987 Continuing Cultural Resource Investigations in the Calvert Prospect: The 1986 Season. Research Report No. 95. Texas Archeological Survey, The University of Texas at Austin. 
Davis, William B.

1974 The Mammals of Texas. Bulletin 41. Texas

Parks and Wildlife Department, Austin.

Day, D. William

1984 Archeological Mitigation at the Doyle Martin Site, 41LN178, and the P. I. Ridge Site, 41FT52, Leon and Freestone Counties, Texas. Document No. 82209. Espey, Huston and Associates, Inc., Austin.

Diamond, David D., David H. Riskind, and Steve L. Orzell

1987 A Framework for Plant Community Classification and Conservation in Texas. The Texas Journal of Science 39(3):203-221.

Ensor, H. Blaine, and Catherine S. Mueller-Wille

1988 Excavations at the Bull Pen Site, 41BP280, Colorado River Drainage, Bastrop County, Texas. Contract Reports in Archaeology, Report Number 3. Texas State Department of Highways and Public Transportation, Highway Design Division, Austin.

Fields, Ross C.

1995 The Archeology of the Post Oak Savannah of East Central Texas. Bulletin of the Texas Archeological Society 66:301-330.

Fields, Ross C. (editor)

1987 Excavations at the Alley Road Site (41LN30), Jewett Mine Project, Leon County, Texas. Reports of Investigations No. 61. Prewitt and Associates, Inc., Austin.

1990 Excavations at the Charles Cox, Lambs Creek Knoll, and Buffalo Branch Sites, Jewett Mine Project, Leon and Freestone Counties, Texas. Reports of Investigations No. 70. Prewitt and Associates, Inc., Austin.

Fields, Ross C., and L. Wayne Klement

1995 Excavations at the Cottonwood Springs Site, Jewett Mine Project, Leon County, Texas. Reports of Investigations No. 102. Prewitt and Associates, Inc., Austin.

Fields, Ross C., L. Wayne Klement, C. Britt Bousman, Steve A. Tomka, Eloise F. Gadus, and Margaret A. Howard

1991 Excavations at the Bottoms, Rena Branch, and Moccasin Springs Sites, Jewett Mine Project, Freestone and Leon Counties, Texas. Reports of Investigations No. 82. Prewitt and Associates, Inc., Austin.
Foster, William C. (editor)

1998 The La Salle Expedition to Texas: The Journal of Henri Joutel, 1684-1687. Texas State Historical Association, Austin.

Frederick, Charles D., Mark D. Bateman, and Paul Lehman

2001 Geoarchaeological Investigations. In National Register Eligibility Testing at 41LE177, Alcoa Sandow Mine, Lee County, Texas: Archaeological, Geoarchaeological, and Paleoevironmental Assessment of an Upland Sandy Mantle Site, by Robert A. Ricklis, pp. 83-123. Coastal Archaeological Research, Inc., Corpus Christi.

Fullem, Bruce B.

1977 The Black Hopper Site. Report No. 10. State Department of Highways and Public Transportation, Highway Design Division, Austin.

Gadus, E. Frances, Ross C. Fields, and Karl W. Kibler

2006 Data Recovery Excavations at the J. B. White Site (41MM341), Milam County, Texas. Archeological Studies Program, Report No. 87, Environmental Affairs Division, Texas Department of Transportation, Austin. Reports of Investigations No. 145, Prewitt and Associates, Inc., Austin.

Gadus, E. Frances, Jennifer K. McWilliams, and Ross C. Fields

2002 Data Recovery Excavations at the McGuire's Garden Site (41FT425), Jewett Mine, Freestone County, Texas. Reports of Investigations No. 134. Prewitt and Associates, Inc., Austin.

Gilmore, Kathleen Kirk

1996a San Francisco Xavier de Horcasitas Mission. In The New Handbook of Texas, Vol. 5, p. 849. The Texas State Historical Association, Austin.

1996b San Ildefonso Mission. In The New Handbook of Texas, Vol. 5, pp. 853-854. The Texas State Historical Association, Austin.

Hester, Thomas R., and Michael B. Collins

1969 Burials from the Frisch Auf! Site: 41FY2 Texas Journal of Science 20(3):261-272. 
Howells, Robert G., Raymond W. Neck, and Harold D. Murray

1996 Freshwater Mussels of Texas. Texas Parks and Wildlife Department, Austin.

Kalter, Ardi J., Robert M. Rogers, and Michael N. Smith

2005 Analysis and Reporting for 41 FY135, the Sandbur Site, Fayette County, Texas. Document No. 020388. PBS\&J, Austin.

Kotter, Steven M., Patience E. Patterson, Dan K. Utley, and Henry B. Moncure

1991 Final Report Of Cultural Resource Investigations at the Cummins Creek Mine, Fayette County, Texas. Studies in Archeology 11. Texas Archeological Research Laboratory, The University of Texas at Austin.

Kutac, Edward A.

1994 Birds. In Birds and Other Wildlife of South Central Texas, by Edward A. Kutac and S. Christopher Caran, pp. 47-102. University of Texas Press, Austin.

Mahoney, Richard B., Steve A. Tomka, Raymond P. Mauldin, Harry J. Shafer, Lee C. Nordt, Russell D. Greaves, and Rebecca R. Galdeano

2003 Data Recovery Excavations at 41MM340: A Late Archaic Site Along Little River in Milam County, Texas. Archeological Studies Program Report No. 54, Environmental Affairs Division, Texas Department of Transportation, Austin. Archaeological Survey Report No. 340, Center for Archaeological Research, The University of Texas at San Antonio.

Mallouf, Michael G.

1979 Archeological Investigations at Lake Limestone. Research Report No. 71. Texas Archeological Survey, The University of Texas at Austin.

McGraw,A. Joachim, John W. Clark Jr., and Elizabeth A. Robbins

1991 A Texas Legacy, The Old San Antonio Road and the Caminos Reales, A Tricentennial History, 1691-1991. Texas Department of Transportation, Environmental Affairs Department, Austin.
McGregor, Daniel E., and James E. Bruseth (editors) 1987 Hunter-Gatherer Adaptations Along the Prairie Margin: Site Excavations and Synthesis of Prehistoric Archaeology. Richland Creek Technical Series, Vol. III. Archaeology Research Program, Institute for the Study of Earth and Man, Southern Methodist University, Dallas.

McLoughlin, Patrick

2002 Geoarcheological Survey of Sections of FM 60 from FM 50 to SH 36, Burleson County, Texas. Letter Report No. 562. Prewitt and Associates, Inc., Austin.

Natural Fibers Information Center

1987 The Climates of Texas Counties. Natural Fibers Information Center, Bureau of Business Research, The University of Texas at Austin.

Newcomb, W. W., Jr.

1993 Historic Indians of Central Texas.Bulletin of the Texas Archeological Society 64:1-63.

Perttula, Timothy K.

2013 Caddo Ceramics in East Texas. Bulletin of the Texas Archeological Society 84:181-212.

Perttula, Timothy K., and Linda E. Ellis

2013 Aboriginal Ceramics Among Groups Living in the Prairie Savanna Region of Texas. Bulletin of the Texas Archeological Society 84:113-135.

Peterson, Fredrick A.

1965 The Erwin's Bridge Site at Somerville Reservoir, Burleson County, Texas. Texas Archeological Salvage Project, The University of Texas at Austin.

Ricklis, Robert A.

2001 National Register Eligibility Testing at 41LE177, Alcoa Sandow Mine, Lee County, Texas: Archaeological, Geoarchaeological, and Paleoenvironmental Assessment of an Upland Sandy Mantle Site. Coastal Archaeological Research, Inc., Corpus Christi.

Robinson, David G., and Solveig A. Turpin

1993 Hunter-Gatherer Mobility and Settlement in the Brazos Uplands: Archeology in the Calvert Mine, Robertson County, EastCentral Texas. Studies in Archeology 14. Texas Archeological Research Laboratory, The University of Texas at Austin. 
Roemer, Erwin, Jr., and Shawn Bonath Carlson 1987 Excavations at 41BU16: State Highway 21 at the Brazos River, Burleson County, Texas. Contract Reports in Archaeology, Report Number 1. Texas State Department of Highways and Public Transportation, Highway Design Division, Austin.

Rogers, Robert

1993 Data Recovery of Three Prehistoric Sites at the Gibbons Creek Third Five-Year Mine Permit Area, Grimes County, Texas. Document No. 910529. Espey, Huston and Associates, Inc., Austin.

1994 Excavations at Site 41GM224 in Gibbons Creek Lignite Mine Permit 38AArea, Grimes County, Texas. Document No. 930476. Espey, Huston and Associates, Inc., Austin.

1995 Excavations at Sites 41GM166, 41GM281 and 41GM282 at the Gibbons Creek Lignite Mine, Grimes County, Texas. Document No. 940611. Espey, Huston and Associates, Inc., Austin.

1997 National Register Testing at Site 41LE120, Lee County, Texas. Document No. 970348. Espey, Huston and Associates, Inc., Austin.

1999 Excavations at the Walleye Creek Site (41LE57), Lee County, Texas. Document No. 981670. Espey, Huston and Associates, Inc., Austin.

Rogers, Robert, and Steve Kotter

1995 Archaeological Investigations at the Chesser Site (41LE59), Lee County, Texas. Document No. 950209. Espey, Huston and Associates, Inc., Austin.

Shafer, Harry J.

1973 Lithic Technology at the George C. Davis Site Cherokee County, Texas. Ph.D. dissertation, Department of Anthropology, The University of Texas at Austin.
2006 People of the Prairie:A Possible Connection to the Davis Site Caddo. Environmental Affairs Division, Texas Department of Transportation, Austin. Prewitt and Associates, Inc., Austin. Electronic document, http://www.counciloftexasarcheologists.org/publications/PrairieCaddo Module.pdf.

Skelton, Duford W.

1977 Archeological Investigations at the Fayette Power Project, Fayette County, Texas. Research Report No. 60. Texas Archeological Survey, The University of Texas at Austin.

Story, Dee Ann

1972 A Preliminary Report of the 1968, 1969, and 1970 Excavations at the George C. Davis Site, Cherokee County, Texas. The University of Texas at Austin.

Suhm, Dee Ann, and Edward B. Jelks

1962 Handbook of Texas Archeology: Type Descriptions. Special Publication No. 1. The Texas Archeological Society. Bulletin No. 4. The Texas Memorial Museum, The University of Texas at Austin.

Thoms, Alston V. (editor)

1993 The Brazos Valley Slopes Archaeological Project: Cultural Resources Assessments for the Texas A\&M University Animal Science Teaching and Research Complex, Brazos County, Texas. Reports of Investigations No. 14.Archaeological Research Laboratory, Texas A\&M University, College Station.

Thoms, Alston V., and Steven W. Ahr

1996 Archaeological Studies at Birch Creek Unit and Yegua Creek Fishing-Access Area, Lake Somerville State Park, Burleson County, Texas, Interim Report, September 1996. Center for Environmental Archaeology, Texas A\&M University, College Station.

Vinson, Carlos

1968 Collecting Shotshells. Gun Digest 22: 91-97. 